Atmos. Chem. Phys., 19, 10845-10864, 2019

https://doi.org/10.5194/acp-19-10845-2019

(C) Author(s) 2019. This work is distributed under

the Creative Commons Attribution 4.0 License.

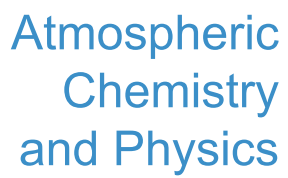

(c) (P)

\title{
Assessing the formation and evolution mechanisms of severe haze pollution in the Beijing-Tianjin-Hebei region using process analysis
}

\author{
Lei Chen ${ }^{1,2}$, Jia Zhu ${ }^{1}$, Hong Liao ${ }^{1}$, Yi Gao ${ }^{3}$, Yulu Qiu ${ }^{4,5}$, Meigen Zhang ${ }^{3,6,7}$, Zirui Liu ${ }^{3}$, Nan Li ${ }^{1}$, and Yuesi Wang \\ ${ }^{1}$ Jiangsu Key Laboratory of Atmospheric Environment Monitoring and Pollution Control, Jiangsu Collaborative Innovation \\ Center of Atmospheric Environment and Equipment Technology, School of Environmental Science and Engineering, \\ Nanjing University of Information Science \& Technology, Nanjing, 210044, China \\ ${ }^{2}$ Key Laboratory of Meteorological Disaster, Ministry of Education (KLME), Joint International Research Laboratory of \\ Climate and Environment Change (ILCEC), Collaborative Innovation Center on Forecast and Evaluation of Meteorological \\ Disasters (CIC-FEMD), Nanjing University of Information Science \& Technology, Nanjing, 210044, China \\ ${ }^{3}$ State Key Laboratory of Atmospheric Boundary Layer Physics and Atmospheric Chemistry, \\ Institute of Atmospheric Physics, Chinese Academy of Sciences, Beijing, 100029, China \\ ${ }^{4}$ Institute of Urban Meteorology, China Meteorological Administration, Beijing 100089, China \\ ${ }^{5}$ Beijing Shangdianzi Regional Atmosphere Watch Station, Beijing, China \\ ${ }^{6}$ University of Chinese Academy of Sciences, Beijing, 100049, China \\ ${ }^{7}$ Center for Excellence in Regional Atmospheric Environment, Institute of Urban Environment, \\ Chinese Academy of Sciences, Xiamen, 361021, China
}

Correspondence: Hong Liao (hongliao@ nuist.edu.cn)

Received: 13 March 2019 - Discussion started: 28 March 2019

Revised: 4 July 2019 - Accepted: 20 July 2019 - Published: 28 August 2019

\begin{abstract}
Fine-particle pollution associated with haze threatens human health, especially in the North China Plain region, where extremely high $\mathrm{PM}_{2.5}$ concentrations are frequently observed during winter. In this study, the Weather Research and Forecasting with Chemistry (WRF-Chem) model coupled with an improved integrated process analysis scheme was used to investigate the formation and evolution mechanisms of a haze event over the Beijing-Tianjin-Hebei (BTH) region in December 2015; this included an examination of the contributions of local emissions and regional transport to the $\mathrm{PM}_{2.5}$ concentration in the BTH area, and the contributions of each detailed physical or chemical process to the variations in the $\mathrm{PM}_{2.5}$ concentration. The mechanisms influencing aerosol radiative forcing (including aerosol direct and indirect effects) were also examined by using process analysis. During the aerosol accumulation stage (1622 December, Stage 1), the near-surface $\mathrm{PM}_{2.5}$ concentration in the BTH region increased from 24.2 to $289.8 \mu \mathrm{g} \mathrm{m}^{-3}$, with the contributions of regional transport increasing from $12 \%$ to $40 \%$, while the contribution of local emissions decreased from $59 \%$ to $38 \%$. During the aerosol dispersion
\end{abstract}

stage (23-27 December, Stage 2), the average concentration of $\mathrm{PM}_{2.5}$ was $107.9 \mu \mathrm{g} \mathrm{m}^{-3}$, which was contributed by local emissions $(51 \%)$ and regional transport $(24 \%)$. The $24 \mathrm{~h}$ change (23:00 minus 00:00 LST) in the near-surface $\mathrm{PM}_{2.5}$ concentration was $+43.9 \mu \mathrm{g} \mathrm{m}^{-3}$ during Stage 1 and $-41.5 \mu \mathrm{g} \mathrm{m}^{-3}$ during Stage 2. The contributions of aerosol chemistry, advection, and vertical mixing to the $24 \mathrm{~h}$ change were $+29.6(+17.9) \mu \mathrm{g} \mathrm{m}^{-3},-71.8(-103.6) \mu \mathrm{g} \mathrm{m}^{-3}$, and $-177.3(-221.6) \mu \mathrm{g} \mathrm{m}^{-3}$ during Stage 1 (Stage 2), respectively. Small differences in the contributions of other processes were found between Stage 1 and Stage 2. Therefore, the $\mathrm{PM}_{2.5}$ increase over the $\mathrm{BTH}$ region during the haze formation stage was mainly attributed to strong production by the aerosol chemistry process and weak removal by the advection and vertical mixing processes. When aerosol radiative feedback was considered, the $24 \mathrm{~h} \mathrm{PM}_{2.5}$ increase was enhanced by $4.8 \mu \mathrm{g} \mathrm{m}^{-3}$ during Stage 1 , which could be mainly attributed to the contributions of the vertical mixing process $\left(+22.5 \mu \mathrm{g} \mathrm{m}^{-3}\right)$, the advection process $\left(-19.6 \mu \mathrm{g} \mathrm{m}^{-3}\right)$, and the aerosol chemistry process $\left(+1.2 \mu \mathrm{g} \mathrm{m}^{-3}\right)$. The restrained vertical mixing was the pri- 
mary reason for the enhancement in the near-surface $\mathrm{PM}_{2.5}$ increase when aerosol radiative forcing was considered.

\section{Introduction}

Anthropogenic activities associated with rapid industrialization and urbanization have been leading to a sustained increase in the amounts of atmospheric pollutants, especially in quickly developing countries (IPCC, 2013). As one of the largest emission sources of aerosols and their precursors, China has been suffering from serious air pollution for years (Lei et al., 2011; Li et al., 2011; Z. Liu et al., 2018), with severe haze events frequently occurring in winter, especially over large urban agglomerations, such as the North China Plain (NCP) (Han et al., 2014; Gao et al., 2015), the Yangtze River Delta (YRD) (Ding et al., 2016; H. Wang et al., 2016), and the Sichuan Basin (SCB) (Zhao et al., 2018; Zhang et al., 2019). During severe haze events, the observed maximum hourly surface-layer $\mathrm{PM}_{2.5}$ (fine particulate matter with an aerodynamic diameter of $2.5 \mu \mathrm{m}$ or less) concentration can exceed $1000 \mu \mathrm{g} \mathrm{m}^{-3}$ (Z. Wang et al., 2013; Sun et al., 2016; J. Li et al., 2017), which can significantly influence visibility (Li et al., 2014), the radiation budget (Steiner et al., 2013), atmospheric circulation (Jiang et al., 2017), cloud properties (Unger et al., 2009), and human health (Hu et al., 2014; Guo et al., 2017).

Extensive studies have been carried out in recent years to analyze the formation mechanisms of haze episodes in China. Y. Wang et al. (2013) used a synergy of ground-based observations, satellite, and lidar measurements to study a long-lasting, severe haze episode that occurred in eastern China in January 2013, and concluded that stagnant meteorological conditions, which can generally be characterized by a low wind speed, high relative humidity, intense inversion, and a low mixing layer height, were tightly associated with severe haze episodes. Based on National Center for Environmental Prediction (NCEP) reanalysis data, Shu et al. (2017) identified five typical synoptic patterns, and pointed out that each synoptic pattern exerted different impacts on particle pollution over the YRD. By analyzing the simulation results from a large ensemble climate model (MIROC5), K. Li et al. (2018) investigated the contributions of the anthropogenic influence to severe haze events that occurred over eastern China in January 2013 and December 2015, and found that anthropogenic forcing (i.e., increased emissions of greenhouse gases) could modify the atmospheric circulation pattern, and that these human-induced circulation changes were conducive to the occurrence of severe haze events. B. Zhang et al. (2015) used a global 3-D chemical transport model (GEOS-Chem) to quantify the local source contributions to wintertime surface-layer $\mathrm{PM}_{2.5}$ concentrations over North China from 2013 to 2015, and reported that emissions from residential and industrial sources and transportation contributed most to the high concentrations of atmospheric aerosols in Beijing. Many studies have also reported that the regional transport of aerosols plays an important role in haze episodes (Z. Wang et al., 2013; Jiang et al., 2015; N. Li et al., 2018). Z. Wang et al. (2013) reported that the "cross-city clusters transport" outside BTH (BeijingTianjin-Hebei) and transport among cities inside the BTH region contributed $20 \%-35 \%$ and $26 \%-35 \%$ of $\mathrm{PM}_{2.5}$ concentrations over BTH, respectively. Secondary aerosol formation and their hygroscopic growth were also confirmed to be a large contributor to severe haze episodes (R. J. Huang et al., 2014; Han et al., 2015; L. Chen et al., 2019). The conversion of $\mathrm{SO}_{2}$ to $\mathrm{SO}_{4}^{2-}$ was strongly associated with high relative humidity, and $\mathrm{NO}_{3}^{-}$was found to be produced mainly by photochemical and heterogeneous reactions (Chen et al., 2016; R. Zhang et al., 2018).

It is well known that aerosols can scatter and absorb solar radiation to alter the radiative balance of the atmosphere and surface (direct radiative effect), and can serve as cloud condensation nuclei or ice nuclei to affect cloud properties (indirect radiative effect) (Twomey, 1974). These impacts are coupled with atmospheric dynamics to produce a chain of interactions with a large range of meteorological variables that influence both weather and climate (Ramanathan et al., 2001; Huang et al., 2006; Li et al., 2017a; Yang et al., 2017), which will further induce feedbacks on aerosol production, accumulation, and even severe haze pollution (Petaja et al., 2016; Li et al., 2017b; Zhao et al., 2017; Gao et al., 2018; Lou et al., 2019). Based on multi-year measurements (from 2010 to 2016), Huang et al. (2018) found that aerosol radiative effects led to a significant heating in the upper planetary boundary layer (PBL) and a substantial dimming at the surface over North China. This is because high concentrations of light-absorbing aerosols were observed, and the aerosolmeteorology interactions depressed the development of the $\mathrm{PBL}$, and, in turn, aggravated the haze pollution (Su et al., 2018). The light-absorbing aerosols can also amplify haze in the NCP region by decreasing East Asian winter monsoon wind speeds via ocean and cloud feedbacks (Lou et al., 2019). Using the WRF-Chem model, Gao et al. (2015) analyzed the feedbacks between aerosols and meteorological fields over the NCP in January 2013, and found that aerosols caused a significant negative (positive) radiative forcing at the surface (in the atmosphere), resulting in a lower surfacelayer wind speed and lower PBL height (PBLH). The average surface-layer $\mathrm{PM}_{2.5}$ concentration increased by 10 $50 \mathrm{\mu g} \mathrm{m}^{-3}$ as a result of the more stable atmosphere. By analyzing the observations from a comprehensive field experiment and simulation results from WRF-Chem model, Q. Liu et al. (2018) concluded that the decreased PBLH associated with increased aerosol concentrations could enhance surfacelayer relative humidity by weakening the vertical transport of water vapor, and that the increased relative humidity at the surface accelerated the formation of secondary particulate matter via heterogeneous reactions, leading to an increase 
of the $\mathrm{PM}_{2.5}$ concentration by $63 \mu \mathrm{g} \mathrm{m}{ }^{-3}$ averaged over the NCP from 15 to 21 December 2016.

All of the studies discussed above revealed that the formation of haze episodes was caused by the synergy impacts of local emissions, regional transport, meteorological conditions, and chemical production. Nevertheless, only the net combined effects on the concentrations of pollutants were provided, without the capability to understand and isolate the atmospheric physical and chemical processes involved. The quantitative assessment of the contributions from each detailed physical/chemical process (e.g., vertical mixing process, advection process, emission source process, aerosol chemistry process and cloud chemistry process) is necessary to fully understand the formation and evolution mechanisms of haze episodes (Gonçalves et al., 2009; Xing et al., 2017; Kang et al., 2019). Furthermore, although many previous studies have identified the positive feedback effects of aerosol radiative forcing on particulate accumulation, the detailed influence mechanisms of the forcing-response relationship at each process chain remain largely elusive (i.e., the prominent physical or chemical processes responsible for the aerosol radiative impacts on haze episodes). Since 2013, substantial efforts have been made to improve air quality in China, including emission reduction and energy transition. However, haze events have continued to frequently occur all over the country. For example, a severe, long-lasting, and wide-ranging haze episode was observed in December 2015 over central and eastern China, with the regional average $\mathrm{PM}_{2.5}$ concentration exceeding $150 \mu \mathrm{g} \mathrm{m}^{-3}$. In the BTH region, a red alert for haze (the most serious level) was issued for the period from 20 to 22 December 2015, with the maximum hourly $\mathrm{PM}_{2.5}$ concentration exceeding $1000 \mu \mathrm{g} \mathrm{m}{ }^{-3}$. The formation and evolution mechanisms, and the aerosol radiative feedbacks of this severe haze episode have not yet been fully estimated.

In this study, we develop an improved online integrated process rate (IPR) analysis scheme (i.e., process analysis) in the fully coupled online Weather Research and Forecasting with Chemistry (WRF-Chem) model, to investigate the formation and evolution mechanisms of the severe haze episode that occurred over the NCP from 16 to 29 December 2015. Sensitivity experiments are conducted to examine the contributions of local emissions and regional transport to the $\mathrm{PM}_{2.5}$ concentrations during the haze episode, while IPR analysis is used to quantify the contributions of each detailed physi$\mathrm{cal} / \mathrm{chemical}$ process to the variations in the $\mathrm{PM}_{2.5}$ concentrations. The effects of aerosol radiative forcing, including the direct and indirect effects, on meteorological parameters and $\mathrm{PM}_{2.5}$ levels during the haze episode are also quantified, with a special focus on the detailed influence mechanism. We hope that the results from this study may provide a better understanding of the formation mechanisms for severe haze events, and help policy makers design and carry out targeted measures to improve air quality over North China.
This paper is arranged as follows. The model configuration, integrated process rate (IPR) analysis (i.e., process analysis), numerical experiments, and observations are presented in Sect. 2. Model evaluation is conducted in Sect. 3. The formation and evolution mechanisms of the haze episode are investigated in Sect. 4. Section 5 provides the impacts of aerosol radiative forcing. Summaries and discussions are presented in Sect. 6.

\section{Methods}

\subsection{Model configuration}

A fully coupled online Weather Research and Forecasting with Chemistry model (WRF-Chem v3.7) is used to simulate meteorological fields and concentrations of gases and aerosols simultaneously (Skamarock et al., 2008; Grell et al., 2005). The WRF-Chem model is designed with two domains using 219 (west-east) $\times 159$ (south-north) and 150 (westeast) $\times 111$ (south-north) grid points at the horizontal resolutions of 27 and $9 \mathrm{~km}$, respectively (Fig. 1). The outer domain covers nearly the whole of East Asia, and the inner domain is located in the NCP. In order to minimize the impacts from LBCs (lateral boundary conditions), we only analyze the simulation results from the inner region of the second domain (i.e., BTH), following Chen et al. (2018) and Wu et al. (2012). The vertical dimension is resolved by 29 full sigma levels, with 15 layers located in the bottom $2 \mathrm{~km}$ for finer resolution in the PBL; the height of the first layer averaged in BTH is about $30 \mathrm{~m}$.

Meteorological initial and lateral boundary conditions used in the WRF-Chem model are taken from the NCEP (National Center for Environmental Prediction) (Final) Operational Global Analysis data with a spatial resolution of $1^{\circ} \times 1^{\circ}$. Four-dimensional data assimilation (FDDA) with the nudging coefficient of $3.0 \times 10^{-4}$ for wind (in and above the PBL), temperature (above the PBL), and water vapor mixing ratio (above the PBL) is adopted to improve the accuracy of simulation results (no analysis nudging is included for the inner domain) (Lo et al., 2008; Otte, 2008; L. Wang et al., 2016; Werner et al., 2016). The forecasts from the MOZART4 global chemical transport model are processed to provide the chemical initial and boundary conditions for the WRFChem model (Emmons et al., 2010).

Anthropogenic emission data are obtained from the MIX Asian emission inventory (http://www.meicmodel.org/ dataset-mix.html, last access: 12 August 2019), with a horizontal resolution of $0.25^{\circ}$ (M. Li et al., 2017). MIX is developed to support the MICS-Asia III (Model Inter-Comparison Study for Asia Phase III) and the TF HTAP (Task Force on Hemispheric Transport of Air Pollution) projects. This inventory includes $\mathrm{SO}_{2}$ (sulfur dioxide), $\mathrm{NO}_{x}$ (nitrogen oxides), $\mathrm{CO}$ (carbon monoxide), $\mathrm{CO}_{2}$ (carbon dioxide), NMVOC (non-methane volatile organic compounds), $\mathrm{NH}_{3}$ (ammo- 


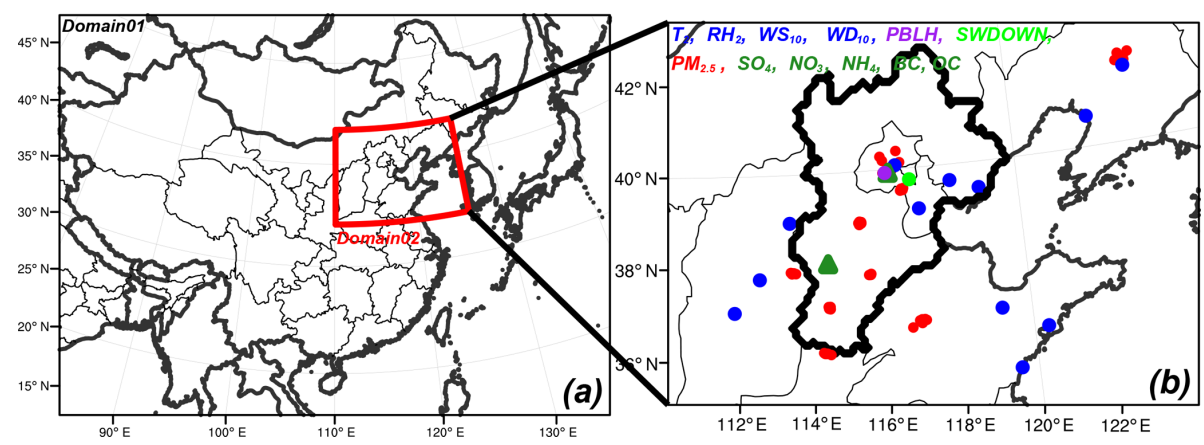

Figure 1. (a) Map of the two nested model domains. (b) Locations of the observations used for model evaluation.
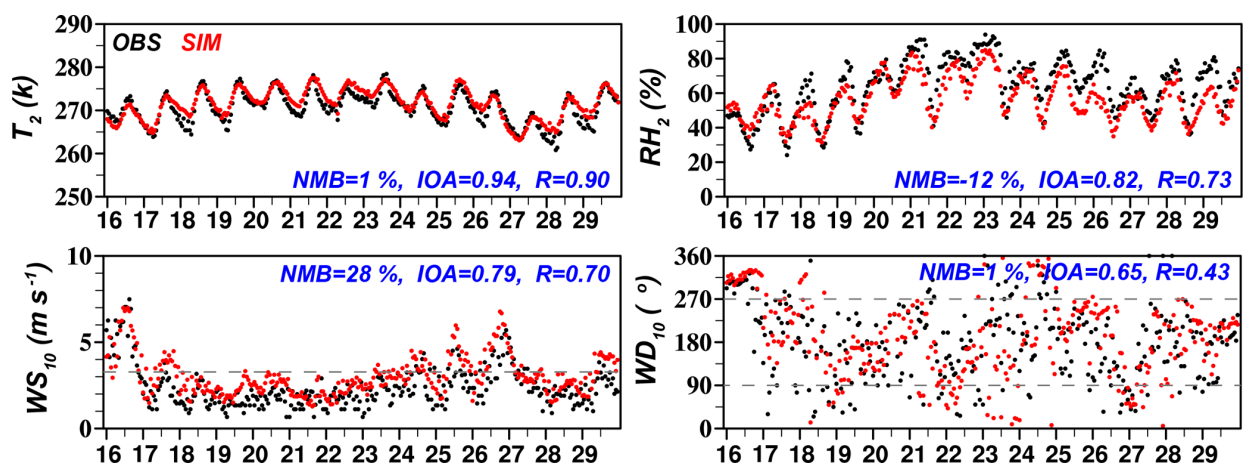

Figure 2. Time series of the observed (black dots) and simulated (red dots) hourly $2 \mathrm{~m}$ temperature $\left(T_{2}, \mathrm{~K}\right), 2 \mathrm{~m}$ relative humidity $\left(\mathrm{RH}_{2}, \%\right)$, $10 \mathrm{~m}$ wind speed $\left(\mathrm{WS}_{10}, \mathrm{~m} \mathrm{~s}^{-1}\right)$, and $10 \mathrm{~m}$ wind direction $\left(\mathrm{WD}_{10},{ }^{\circ}\right)$ averaged over the 12 stations from 16 to 29 December 2015.

nia), BC (black carbon), OC (organic carbon), $\mathrm{PM}_{2.5}$, and $\mathrm{PM}_{10}$. All of these species are from several sectors, such as agriculture, industry, power, transportation, and residential, and the emission rate of each species for each hour is based on Gao et al. (2015). The biogenic emissions are calculated online using the MEGANv2.04 (Model of Emission of Gases and Aerosol from Nature v2.04) model (Guenther et al., 2006). Biomass-burning emissions are obtained from the GFEDv3 (Global Fire Emissions Database v3) (Randerson et al., 2005). Dust emissions and sea salt emissions are calculated online using algorithms proposed by Shao (2004) and Gong et al. (1997), respectively.

The Carbon-Bond Mechanism version Z (CBMZ) (Zaveri and Peters, 1999) is selected to simulate the gas-phase chemistry, and the eight-bin sectional aerosol module, MOSAIC (Model for Simulating Aerosol Interactions and Chemistry) (Zaveri et al., 2008), with some aqueous chemistry, is used to simulate aerosol evolution. All major aerosol species are considered in the MOSAIC scheme, including sulfate $\left(\mathrm{SO}_{4}^{2-}\right)$, nitrate $\left(\mathrm{NO}_{3}^{-}\right)$, ammonium $\left(\mathrm{NH}_{4}^{+}\right)$, chloride $(\mathrm{Cl})$, sodium $(\mathrm{Na}), \mathrm{BC}$, primary organic mass, liquid water, and other inorganic mass (Zaveri et al., 2008). The aerosol size distribution is divided into discrete size bins defined by their lower and upper dry particle diameters (Zhao et al., 2010). In the current CBMZ/MOSAIC scheme, the formation of SOA (secondary organic aerosol) is not included (Zhang et al.,
2012; Gao et al., 2016). Aerosol optical properties, including the extinction efficiency, the single scatter albedo, and the asymmetry factor are computed using Mie theory, based on aerosol composition, mixing state, and size distribution (Barnard et al., 2010). The impacts of aerosols on photolysis rates are calculated using the Fast-J photolysis scheme (Wild et al., 2010). Aerosol radiation is simulated using RRTMG (Rapid Radiative Transfer Model for GCMs) for both shortwave (SW) and longwave (LW) radiation (Zhao et al., 2011). More information regarding the parameterizations used in this study can be found in Table 1 .

\subsection{Integrated process rate (IPR) analysis}

Most air quality models are configured to output only the pollutant concentrations that reflect the combined effects of all physical and chemical processes. Quantitative information on the impacts of individual process is usually unavailable. Process analysis techniques, i.e., integrated process rate (IPR) analysis, can be used in grid-based Eulerian models (e.g., WRF-Chem) to obtain contributions of each phys$\mathrm{ical} /$ chemical process to variations in pollutant concentrations. Eulerian models utilize the numerical technique of operator splitting to solve continuity equations for each species into several simple ordinary differential equations or partial 
Table 1. Parameterizations used in the WRF-Chem model.

\begin{tabular}{ll}
\hline Options & WRF-Chem \\
\hline Microphysics option & Purdue Lin scheme \\
Longwave radiation option & RRTMG scheme \\
Shortwave radiation option & RRTMG scheme \\
Surface layer option & Revised MM5 Monin-Obukhov scheme \\
Land surface option & Unified Noah land-surface model \\
Urban canopy model & Single-layer UCM scheme \\
Boundary layer option & YSU scheme \\
Cumulus option & Grell 3-D ensemble scheme \\
Photolysis scheme & Fast-J \\
Dust scheme & Shao_2004 \\
Chemistry option & CBMZ \\
Aerosol option & MOSAIC \\
Analysis nudging & On \\
\hline
\end{tabular}

differential equations that only contain the influence of one or two processes (Gipson, 1999).

The IPR analysis method has been fully implemented in Community Multi-scale Air Quality (CMAQ) model, and has been widely applied to study regional photochemical ozone $\left(\mathrm{O}_{3}\right)$ pollution (Gonçalves et al., 2009; Khiem et al., 2010; Xing et al., 2017; Tang et al., 2017). Several WRF-Chem model studies have used the IPR analysis to investigate the impacts of physical/chemical process on variations in $\mathrm{O}_{3}$ concentrations. Gao et al. (2018) investigated the impacts of BC-PBL interactions on $\mathrm{O}_{3}$ concentrations by analyzing the contributions from photochemistry, vertical mixing, and advection processes. Jiang et al. (2012) calculated the contributions of photochemical reactions and physical processes to $\mathrm{O}_{3}$ formation using a simplified IPR analysis scheme.

Applying the IPR analysis to diagnose the contributions of each physical or chemical process to variations in aerosol concentrations in the WRF-Chem model is more complex technically; therefore, few studies have utilized the IPR analysis for aerosols. In this study, we developed an improved IPR analysis scheme in the WRF-Chem model to isolate the processes impacting variations in aerosol concentrations into nine different processes, namely advection (TRAN), emission source (EMIS), dry deposition (DYRD), turbulent diffusion (DIFF), sub-grid convection (SGCV), gas-phase chemistry (GASC), cloud chemistry (CLDC), aerosol chemistry (AERC), and wet scavenging (WETP). TRAN includes horizontal and vertical advection, which is highly related to wind and aerosol concentration gradients from upwind regions to downwind areas (Gao et al., 2018). DRYD is based on resistance models for trace gases (Wesely, 1989) and aerosol particles (Ackermann et al., 1998). SGCV refers to the scavenging within the sub-grid wet convective updrafts. CLDC refers to aqueous-phase photolytic and radical chemistry reactions in clouds, including the activation processes. AERC refers to microphysical nucleation, condensation, and coagulation, as well as the mass transfer between the gas phase and condensed phase. WETP contains in-cloud rainout and below- cloud washout during grid-scale precipitation. The contribution of individual processes can be calculated as the difference of aerosol concentrations before and after the corresponding operator.

Based on the principle of mass balance, IPR can be verified by comparing the variations in aerosol concentrations (the concentration at the current time minus the concentration at the previous time) with the sum of the contributions from the nine processes during each time step. As shown in Fig. S1 in the Supplement, the net contributions of all processes match the variations in aerosol concentrations quite well.

\subsection{Numerical experiments}

Table 2 summarizes the experimental designs. To investigate the contributions of regional transport and local emissions to the $\mathrm{PM}_{2.5}$ concentrations in the $\mathrm{BTH}$ region, four simulations with different anthropogenic emission categories were conducted: (1) CTL - the control simulation with all anthropogenic emissions considered; (2) NoAnth - no anthropogenic emissions are considered in the whole domain; (3) NoBTH_Anth - the same as the CTL, but anthropogenic emissions in the BTH area are excluded; and (4) OnlyBTH_Anth - contrary to the NoBTH_Anth case, anthropogenic emissions are only considered in the BTH region. All the physical and chemical schemes used in these cases are identical. The contributions of regional transport and local emissions to the $\mathrm{PM}_{2.5}$ concentration in the BTH region can be identified by comparing the simulation results of NoBTH_Anth and NoAnth (i.e., NoBTH_Anth minus NoAnth) and OnlyBTH_Anth and NoAnth (i.e., OnlyBTH_Anth minus NoAnth), respectively.

To quantify the aerosol radiative effects (ARE) on haze pollution, another sensitivity experiment (referred to as the NoARE case) was designed by turning the feedbacks between aerosols and meteorological variables off, including eliminating the aerosol direct effect (ADE) and the aerosol indirect effect (AIE) in the model. The ADE is turned off by removing the mass of aerosol species from the calculation of aerosol optical properties, following Qiu et al. (2017). The AIE is turned off using a prescribed vertically uniform cloud droplet number, which is calculated from the CTL case during the whole simulation period, following Gao et al. (2015) and B. Zhang et al. (2015). The differences between CTL and NoARE (i.e., CTL minus NoARE) represent the impacts of aerosol radiative forcing.

The IPR analysis method is applied to all of the experiments designed. Comparing the contributions of each detailed process between the pollution accumulation stage and the dissipation stage in the CTL case can quantitatively explain the reason for the variation in the $\mathrm{PM}_{2.5}$ concentrations in the BTH region. Meanwhile, the prominent physical or chemical process responsible for the aerosol radiative impacts on the haze episode can also be investigated by ana- 
Table 2. Experimental design. "Y" represents yes, and "N" represents no.

\begin{tabular}{llll}
\hline $\begin{array}{l}\text { Case } \\
\text { description }\end{array}$ & $\begin{array}{l}\text { Anthropogenic } \\
\text { emission }\end{array}$ & $\begin{array}{l}\text { Aerosol direct } \\
\text { effect }\end{array}$ & $\begin{array}{l}\text { Aerosol indirect } \\
\text { effect }\end{array}$ \\
\hline CTL & Y & Y & Y \\
NoAnth & Without emission in the whole domain & Y & Y \\
NoBTH_Anth & Without emission in BTH & Y & Y \\
OnlyBTH_Anth & Only emission in BTH & Y & Y \\
NoARE & Y & N & N \\
\hline
\end{tabular}

lyzing the IPR analysis method used in the CTL and NoARE cases.

All five simulations are conducted for the period from 13 to 29 December 2015, and the initial 3 days are discarded as the model spin-up to minimize the impacts of initial conditions. Simulation results from the CTL case from 16 to 29 December 2015 are used to evaluate the model performance.

\subsection{Observational data}

Simulated meteorological parameters in CTL case, including $2 \mathrm{~m}$ temperature $\left(T_{2}\right), 2 \mathrm{~m}$ relative humidity $\left(\mathrm{RH}_{2}\right), 10 \mathrm{~m}$ wind speed $\left(\mathrm{WS}_{10}\right)$, and $10 \mathrm{~m}$ wind direction $\left(\mathrm{WD}_{10}\right)$, are compared with hourly observations at 12 stations, which are collected from NOAA's National Climatic Data Center (https://gis.ncdc.noaa.gov/maps/ncei/cdo/hourly, last access: 12 August 2019). Due to limited observations of the PBL height in the BTH area, the retrieved PBLH observations at $3 \mathrm{~h}$ intervals obtained from the GDAS (Global Data Assimilation System) (https://ready.arl.noaa.gov/READYamet. php, last access: 12 August 2019) in Beijing $\left(39.93^{\circ} \mathrm{N}\right.$, $116.28^{\circ} \mathrm{E}$ ) are also used to evaluate the model performance. More detailed information about the GDAS meteorological dataset $\left(1^{\circ} \times 1^{\circ}\right)$ can be found in Rolph (2013), Kong et al. (2015), and at https://www.ready.noaa.gov/gdas1.php (last access: 12 August 2019). The hourly shortwave downward radiation flux (SWDOWN) at the Xianghe station $\left(39.75^{\circ} \mathrm{N}, 116.96^{\circ} \mathrm{E}\right)$ is taken from WRMC-BSRN (World Radiation Monitoring Center-Baseline Surface Radiation Network, http://bsrn.awi.de, last access: 12 August 2019) for the energy budget evaluation. The hourly observed surfacelayer $\mathrm{PM}_{2.5}$ concentrations at the 59 stations are obtained from the CNEMC (China National Environmental Monitoring Center, http://www.cnemc.cn/, last access: $12 \mathrm{Au}-$ gust 2019). The daily measurements of the mass concentrations of $\mathrm{SO}_{4}^{2-}, \mathrm{NO}_{3}^{-}, \mathrm{NH}_{4}^{+}, \mathrm{BC}$, and $\mathrm{OC}$ are collected at the Beijing $\left(39.97^{\circ} \mathrm{N}, 116.37^{\circ} \mathrm{E}\right)$ and Shijiazhuang $\left(38.03^{\circ} \mathrm{N}\right.$, $114.53^{\circ} \mathrm{E}$ ) sites (Huang et al., 2017; Z. Liu et al., 2018). Detailed locations of these observations are shown in Fig. $1 \mathrm{~b}$.

\section{Model evaluation}

Accurate representations of observed meteorological fields and pollutant concentrations provide foundations for haze analysis with the WRF-Chem model. Detailed comparisons between observed and simulated meteorological parameters $\left(T_{2}, \mathrm{RH}_{2}, \mathrm{WS}_{10}, \mathrm{WD}_{10}, \mathrm{PBLH}\right.$, and SWDOWN) and pollutant concentrations $\left(\mathrm{PM}_{2.5}, \mathrm{BC}, \mathrm{OC}, \mathrm{SO}_{4}^{2-}, \mathrm{NO}_{3}^{-}\right.$, and $\left.\mathrm{NH}_{4}^{+}\right)$ are presented in this section.

\subsection{Meteorological parameters}

Figure 2 shows the time series of observed and simulated hourly meteorological variables averaged over the 12 stations from 16 to 29 December 2015. Corresponding statistical metrics, including the mean value, the normalized mean bias (NMB), the mean fractional bias (MFB), the mean fractional error (MFE), the index of agreement (IOA), and the correlation coefficient $(R)$ are presented in Table 3. As shown in Fig. 2, simulated $T_{2}, \mathrm{RH}_{2}, \mathrm{WS}_{10}$, and $\mathrm{WD}_{10}$ agree well with the observational data. For temperature, the WRF-Chem model can perfectly depict its diurnal and daily variations with $R$ and IOA values of 0.90 and 0.94 , respectively, but slightly overestimates the low values at night, with a NMB of $1 \%$. Observed relative humidity can be reasonably reproduced by the model with $R$ and IOA values of 0.73 and 0.82 , respectively, but a persistent underestimation is found with a NMB of $-12 \%$. Different surface layer and boundary layer parameterizations may influence the simulated near-surface moisture fluxes, and the settings of these schemes can partially explain the biases of $\mathrm{RH}_{2}$ between the observations and simulations (Qian et al., 2016). This negative bias of $\mathrm{RH}_{2}$ can also be simulated by other studies (Zhang et al., 2009; Gao et al., 2015). WRF-Chem can capture the observed low wind speed values from 19 to 23 December and high wind speed values from 16 to 17 and 25 to 27 December. The positive NMB of $28 \%$ probably results from unresolved topographical features in the surface drag parameterization and the coarse resolution used in the nested domain (Yahya et al., 2015; Zheng et al., 2015). For wind direction, the calculated NMB is $1 \%$ and the IOA is 0.65 , indicating that the WRF-Chem model can generally reproduce the varied wind direction during the simulation period. 
Table 3. Statistical metrics between observations and simulations.

\begin{tabular}{lrrrrrrrr}
\hline Variables & $n$ & $\overline{\mathrm{OBS}}^{\mathrm{a}}$ & $\overline{\mathrm{SIM}}^{\mathrm{b}}$ & $\mathrm{NMB}^{\mathrm{c}}$ & $\mathrm{MFB}^{\mathrm{d}}$ & $\mathrm{MFE}^{\mathrm{e}}$ & $\mathrm{IOA}^{\mathrm{f}}$ & $R^{\mathrm{g}}$ \\
\hline$T_{2}(\mathrm{~K})^{\mathrm{h}}$ & 12 & 270.7 & 271.6 & 1 & 1 & 1 & 0.94 & 0.90 \\
$\mathrm{RH}_{2}(\%)^{\mathrm{h}}$ & 12 & 63.8 & 56.1 & -12 & -12 & 22 & 0.82 & 0.73 \\
$\mathrm{WS}_{10}\left(\mathrm{~m} \mathrm{~s}^{-1}\right)^{\mathrm{h}}$ & 12 & 2.5 & 3.2 & 28 & 32 & 58 & 0.79 & 0.70 \\
$\mathrm{WD}_{10}\left({ }^{\circ}\right)^{\mathrm{h}}$ & 12 & 190.8 & 192.2 & 1 & -2 & 55 & 0.65 & 0.43 \\
$\mathrm{PM}_{2.5}\left(\mu \mathrm{g} \mathrm{m}^{-3}\right)$ & 59 & 173.6 & 168.2 & -3 & 13 & 47 & 0.86 & 0.76 \\
\hline
\end{tabular}

$\mathrm{a}, \mathrm{b} \overline{\mathrm{OBS}}$ and $\overline{\mathrm{SIM}}$ represent the average observations and simulations, respectively. $\overline{\mathrm{OBS}}=\frac{1}{\mathrm{n}} \times \sum_{i=1}^{\mathrm{n}} \mathrm{OBS}_{i}$, $\overline{\operatorname{SIM}}=\frac{1}{\mathrm{n}} \times \sum_{i=1}^{\mathrm{n}} \mathrm{SIM}_{i}$.

${ }^{\mathrm{c}}$ NMB is the normalized mean bias, $\mathrm{NMB}=\frac{1}{\mathrm{n}} \times \sum_{i=1}^{\mathrm{n}} \frac{\mathrm{SIM}_{i}-\mathrm{OBS}_{i}}{\mathrm{OBS}_{i}} \times 100 \%$.

$\mathrm{d}$ MFB is the mean fractional bias, MFB $=\frac{2}{\mathrm{n}} \times \sum_{i=1}^{\mathrm{n}} \frac{\operatorname{SIM}_{i}-\mathrm{OBS}_{i}}{\operatorname{SIM}_{i}+\mathrm{OBS}_{i}} \times 100 \%$.

e MFE is the mean fractional error, MFE $=\frac{2}{\mathrm{n}} \times \sum_{i=1}^{\mathrm{n}} \frac{\left|\mathrm{SIM}_{i}-\mathrm{OBS}_{i}\right|}{\mathrm{SIM}_{i}+\mathrm{OBS}_{i}} \times 100 \%$.

${ }^{\mathrm{f}} \mathrm{IOA}$ is the index of agreement, $\mathrm{IOA}=1-\frac{\sum_{i=1}^{\mathrm{n}}\left(\mathrm{SIM}_{i}-\mathrm{OBS}_{i}\right)^{2}}{\left.\sum_{i=1}^{\mathrm{n}}\left(\left|\mathrm{OBS}_{i}-\overline{\mathrm{OBS}}\right|+\mid \mathrm{SIM}_{i}-\overline{\mathrm{SIM}}\right) \mid\right)^{2}}$.

$\mathrm{g} R$ is the correlation coefficient, $R=\frac{\sum_{i}^{\mathrm{n}}\left|\left(\mathrm{OBS}_{i}-\overline{\mathrm{OBS}}\right) \times\left(\mathrm{SIM}_{i}-\overline{\mathrm{SIM}}\right)\right|}{\sqrt{\sum_{i}^{\mathrm{n}}\left(\mathrm{OBS}_{i}-\overline{\mathrm{OBS}}\right)^{2}+\sum_{i}^{\mathrm{n}}\left(\mathrm{SIM}_{i}-\overline{\mathrm{SIM}}\right)^{2}}}$

In the above $\mathrm{OBS}_{i}$ and $\mathrm{SIM}_{i}$ refer to observations and model predictions, respectively, $i$ refers to a given station, and $\mathrm{n}$ is the total number of stations.

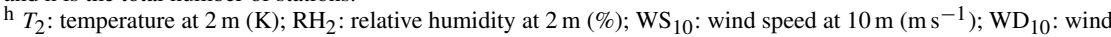
direction at $10 \mathrm{~m}\left({ }^{\circ}\right)$.
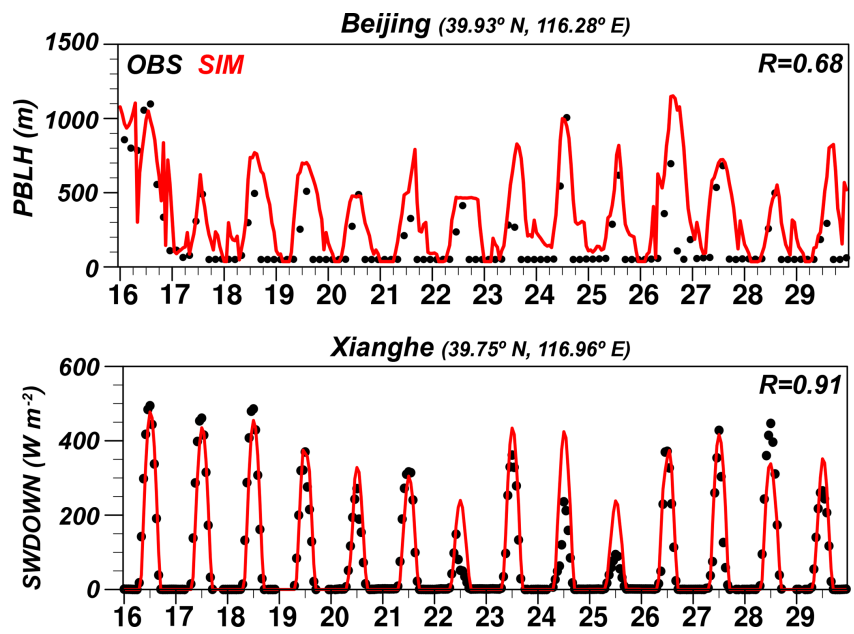

Figure 3. Time series of the observed (black dots) and simulated (red lines) hourly planetary boundary layer height (PBLH, $\mathrm{m}$ ) at the site in Beijing $\left(39.93^{\circ} \mathrm{N}, 116.28^{\circ} \mathrm{E}\right)$, and shortwave downward radiation flux (SWDOWN, W m ${ }^{-2}$ ) at the Xianghe station $\left(39.75^{\circ} \mathrm{N}\right.$, $116.96^{\circ} \mathrm{E}$ ) from 16 to 29 December 2015. Notably, PBLH measurements provided by Global Data Assimilation System (GDAS) are in $3 \mathrm{~h}$ intervals. All times are converted to China standard time (Beijing time).

Simulated hourly PBLH and SWDOWN are also compared with observations in Fig. 3. It is noted that the PBLH measurements provided by GDAS of NOAA are in $3 \mathrm{~h}$ intervals. The simulations in the CTL case agree well with the observations, including capturing the daily maximum at daytime and the low values at night. The correlation coefficients are 0.68 and 0.91 for PBLH and SWDOWN, respectively.

\section{2 $\mathrm{PM}_{2.5}$ and its components}

Observed hourly surface-layer $\mathrm{PM}_{2.5}$ concentrations from 16 to 29 December 2015 in the nine cities (Shengyang, Beijing, Xingtai, Hengshui, Baoding, Langfang, Yangquan, Anyang, and Jinan) are compared with the model results from the CTL case (Fig. 4). The statistical metrics are shown in Table 3. Generally, the WRF-Chem model can reasonably reproduce the evolutional characteristics of the observed $\mathrm{PM}_{2.5}$ concentrations in the nine cities ( $R s=0.57-0.90)$. Both the observed and simulated $\mathrm{PM}_{2.5}$ concentrations exhibit a growth trend from 16 to 22 and 28 to 29 December, and a decreasing tendency from 23 to 27 December. However, an obvious underestimation is found in Beijing from 25 to 26 December when a maximum hourly concentration of $600 \mathrm{\mu gm}^{-3}$ was observed. This negative bias is also simulated by previous studies (Chen et al., 2018; Z. Zhang et al., 2018). The possible reasons for the underestimation are as follows: (1) the bias in simulated meteorological conditions (e.g., underestimated $\mathrm{RH}_{2}$ and overestimated $\mathrm{WS}_{10}$ ); (2) the missing mechanisms of some gas-aerosol phase partitioning and heterogeneous reactions which may produce secondary inorganic aerosol (X. Huang et al., 2014; Wang et al., 2014); and (3) the lack of SOA simulation in the MOSAIC mechanism (Gao et al., 2016). Generally, the performance statistics of $\mathrm{PM}_{2.5}$ in almost all cities meet the model performance goal (MFB within $\pm 30 \%$ and MFE $\leq 50 \%$ ) proposed by Boylan and Russel (2006).

Figure 5 compares the simulated and observed surfacelayer concentrations of $\mathrm{BC}, \mathrm{OC}, \mathrm{SO}_{4}^{2-}, \mathrm{NO}_{3}^{-}$, and $\mathrm{NH}_{4}^{+}$in Beijing and Shijiazhuang averaged from 16 to 29 December 2015. The WRF-Chem model underestimates the con- 

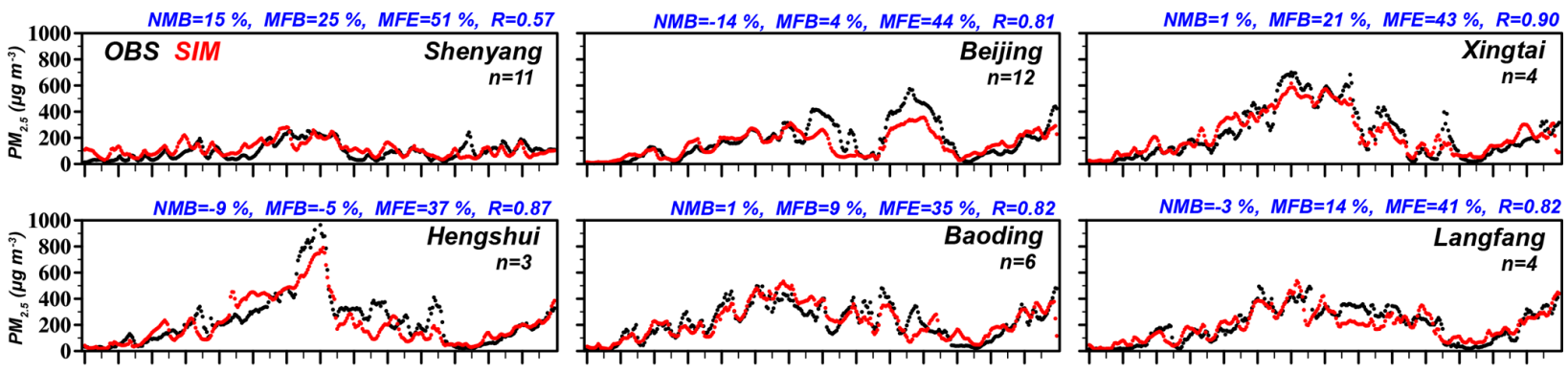

$N M B=-3 \%, M F B=14 \%$, MFE $=41 \%, R=0.82$
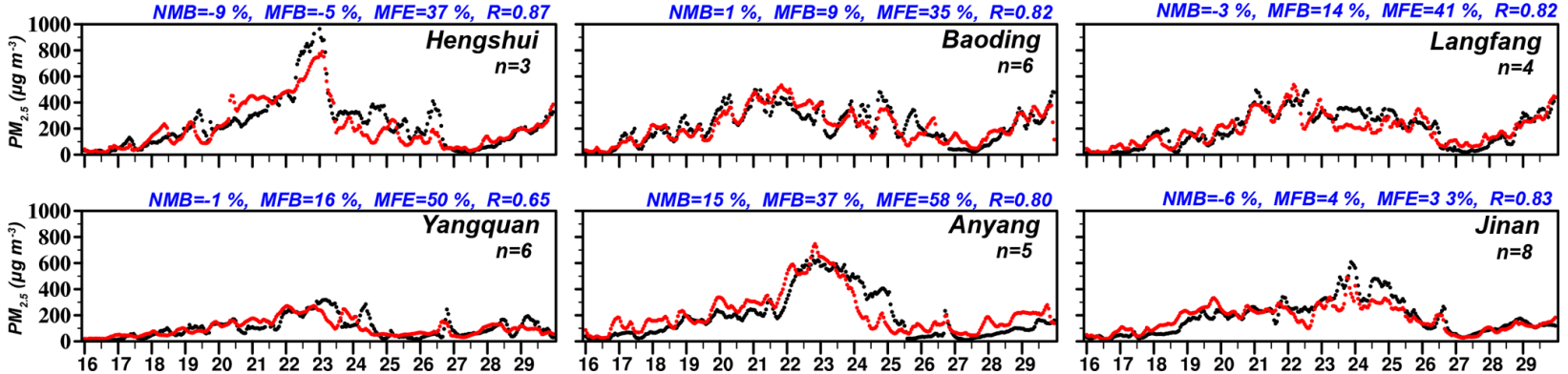

$N M B=-6 \%, M F B=4 \%, M F E=33 \%, R=0.83$

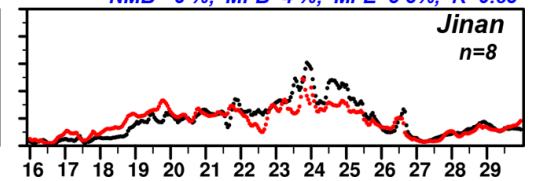

Figure 4. Time series of the observed (black dots) and simulated (red dots) hourly $\mathrm{PM}_{2.5}$ concentrations $\left(\mu \mathrm{g} \mathrm{m}^{-3}\right.$ ) in the nine cities (Shengyang, Beijing, Xingtai, Hengshui, Baoding, Langfang, Yangquan, Anyang, and Jinan) from 16 to 29 December 2015 . The " $n$ " in each panel represents the number of observation sites in each city. Beijing time is used for these hourly time series.

centrations of $\mathrm{SO}_{4}^{2-}, \mathrm{NH}_{4}^{+}$, and $\mathrm{OC}$ in Beijing (Shijiazhuang) by $19 \%(40 \%), 14 \%(9 \%)$, and $21 \%(41 \%)$, respectively, but overestimates the $\mathrm{NO}_{3}^{-}$concentration by $29 \%$ (44\%). Due to the low reactivity of $\mathrm{BC}$ in the atmosphere, the uncertainty in the $\mathrm{BC}$ emissions may cause the biases in Beijing $(\mathrm{NMB}=+10 \%)$ and Shijiazhuang $(\mathrm{NMB}=-24 \%)$. For OC, the underestimation may result from the lack of SOA in the MOSAIC aerosol module (Qiu et al., 2017). Missing some $\mathrm{SO}_{2}$ gas-phase and aqueous-phase oxidation mechanisms, as well as heterogeneous chemistry may explain the underestimation of $\mathrm{SO}_{4}^{2-}$. It is noted that similar biases of aerosol components were also reported by other WRF-Chem studies (B. Zhang et al., 2015; Qiu et al., 2017).

\section{Formation and evolution mechanisms of the haze episode}

In this section, we first reproduce the evolution of the severe haze episode, and then investigate the formation and evolution mechanisms, including examining contributions of local emissions and regional transport to the $\mathrm{PM}_{2.5}$ concentration in the BTH region, and the contributions of each detailed physical/chemical process to the variations in the $\mathrm{PM}_{2.5}$ concentration.

\subsection{Spatial-temporal evolutions of surface-layer $\mathbf{P M}_{2.5}$ concentrations}

Figure $6 \mathrm{a}-\mathrm{k}$ show the spatial distributions of the simulated daily mean surface-layer $\mathrm{PM}_{2.5}$ concentrations from 17 to 28 December 2015. From 17 December, aerosol particles started to accumulate in the near-surface layer in the BTH region under a prevailing southerly air flow. On 20 December, the BTH area was under a uniform pressure field (Fig. S2a). The regional average wind speed was less than

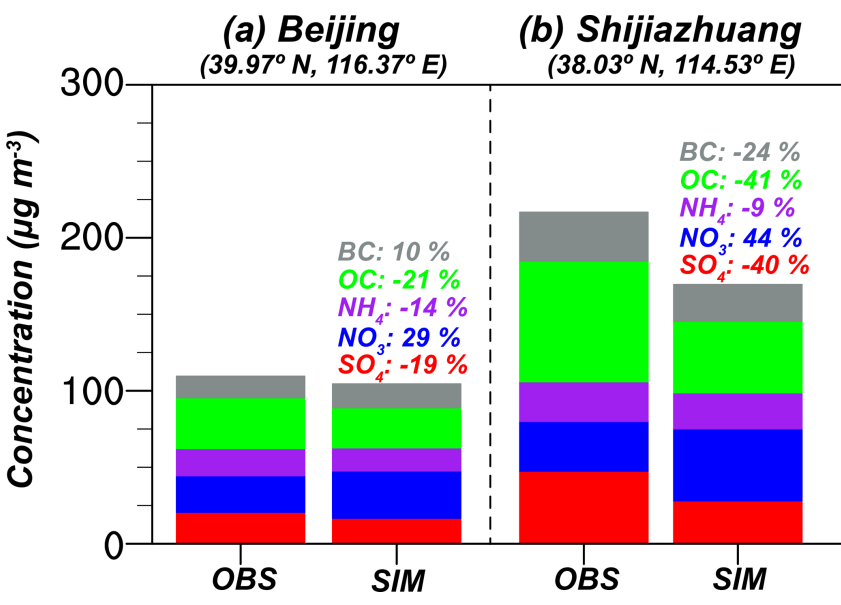

Figure 5. Comparison of observed and simulated surface-layer mass concentrations $\left(\mu \mathrm{g} \mathrm{m}^{-3}\right.$ ) of $\mathrm{SO}_{4}^{2-}$ (red), $\mathrm{NO}_{3}^{-}$(blue), $\mathrm{NH}_{4}^{+}$ (purple), OC (green), and $\mathrm{BC}$ (gray) at sites (a) in Beijing $\left(39.97^{\circ} \mathrm{N}, 116.37^{\circ} \mathrm{E}\right)$ and (b) Shijiazhuang $\left(38.03^{\circ} \mathrm{N}, 114.53^{\circ} \mathrm{E}\right)$ averaged over the 16-29 December 2015 period. Normalized mean biases (NMBs) are also listed for each species (colored numbers).

$3 \mathrm{~m} \mathrm{~s}^{-1}$, and the boundary layer became stable, which constrained aerosols within a low mixing layer. Meanwhile, a low-pressure center was situated to the north of the BTH region, where air pollutants from south, southwest, and southeast converged. Consequently, the daily mean $\mathrm{PM}_{2.5}$ concentration averaged over the BTH area was over $200 \mu \mathrm{g} \mathrm{m}^{-3}$. On 21 December, a weak low-pressure center formed near Bohai Bay and a weak high-pressure center moved to the Shandong Peninsula (Fig. S2b). The synoptic conditions brought more air masses from south to north, and worsened air quality in the BTH region. On 22 December, a weak high-pressure system moved within Inner Mongolia (Fig. S2c), which carried cold air to the BTH region. Meanwhile, the polluted air was 
also transported back to the BTH, leading to a continuous increase in the $\mathrm{PM}_{2.5}$ concentration, with the maximum daily mean value exceeding $600 \mathrm{\mu g} \mathrm{m}^{-3}$ (Fig. 6e). Due to the enhanced anticyclone originating from Siberia (Fig. S2d), the accumulation of aerosol particles in the BTH region was terminated by the incursion of a strong cold front from 23 to 27 December. However, frequent transitions between highand low-pressure systems over the BTH area accompanied by shifting wind directions resulted in a rapid $\mathrm{PM}_{2.5}$ variation, especially on 24 and 25 December, when a low-pressure system developed northeast of BTH (Fig. S2e). The air mass over BTH was influenced by the pollutants from the south, resulting in a temporary increase in the concentration of $\mathrm{PM}_{2.5}$ on 25 December. After 27 December, another haze episode gradually formed.

According to the trends in simulated $\mathrm{PM}_{2.5}$ concentrations averaged over the BTH region (Fig. 61), we divide the whole simulation period into three stages: (1) the aerosol accumulation stage (16-22 December, Stage 1), (2) the aerosol dispersion stage (23-27 December, Stage 2), and (3) the formation stage for another haze event (28-29 December, Stage 3). In this paper, we mainly focus on the first two stages to reveal important factors that cause the accumulation and dispersion of particulate matter.

In Stage 1 , the daily mean $\mathrm{PM}_{2.5}$ concentrations averaged over the BTH region increased from 24.2 to $289.8 \mu \mathrm{g} \mathrm{m}^{-3}$, and the average $\mathrm{PM}_{2.5}$ concentration was $145.6 \mu \mathrm{g} \mathrm{m}^{-3}$ (Fig. 7a), which is close to the "heavily polluted" air quality threshold value $\left(\mathrm{PM}_{2.5} 24 \mathrm{~h}\right.$ average concentration $>150 \mu \mathrm{g} \mathrm{m}^{-3}$ ). The $\mathrm{WS}_{10}$ was low (Fig. 7b), especially during the heavily pollution period (20-22 December), and the mean wind speed was $2.3 \mathrm{~m} \mathrm{~s}^{-1}$, which is less than $3.2 \mathrm{~m} \mathrm{~s}^{-1}$ (one of the indicators used to define air stagnation by NOAA, https://www.ncdc.noaa.gov/ societal-impacts/air-stagnation/overview, last access: $12 \mathrm{Au}$ gust 2019), indicating that the near-surface circulation was insufficient to disperse accumulated air pollutants. The decreased PBLH (from 701.6 to $109.9 \mathrm{~m}$ ) could compress air pollutants into a shallow layer, resulting in an elevated pollution level. During Stage 2, the $\mathrm{PM}_{2.5}$ concentration decreased gradually with the increased wind speed and PBLH. The average $\mathrm{PM}_{2.5}$ concentration during Stage 2 was $107.9 \mu \mathrm{g} \mathrm{m}^{-3}$, which still exceeded the Grade II standard $\left(75 \mu \mathrm{g} \mathrm{m}^{-3}\right)$ defined by the National Ambient Air Quality Standards of China.

\subsection{Contributions of local emissions and regional transport to $\mathbf{P M}_{2.5}$ concentrations}

Previous studies have reported that anthropogenic emissions are the dominant cause of haze events in China (Jiang et al., 2013; Sun et al., 2014; Gu and Liao, 2016; Y. Yang et al., 2016). Emission control measures have been taken to ensure good air quality for major events (e.g., APEC) or to mitigate the severity of coming pollution episodes (Zhou et al.,
2018). Other studies, such as Sun et al. (2017) and Wang et al. (2017), have pointed out that regional transport contributed more than $50 \%$ of the particulate concentrations in the BTH region during haze events. This section discusses the contributions of local anthropogenic emission and regional transport to the $\mathrm{PM}_{2.5}$ concentration in the BTH area, aiming to reveal their relative importance during this haze episode.

As shown in Fig. 7a, the $\mathrm{PM}_{2.5}$ concentration in BTH during Stage 1 was mainly contributed by the combined effects of local emissions and regional transport. The contributions of local emissions and regional transport to the $\mathrm{PM}_{2.5}$ concentration were comparable ( $49 \%$ and $32 \%$, respectively), especially during the heavy pollution period (20-22 December, $43 \%$ vs. $37 \%$ ). During Stage 2, the contributions of regional transport decreased from $30 \%$ to $16 \%$. The relative high $\mathrm{PM}_{2.5}$ concentration $\left(107.9 \mu \mathrm{g} \mathrm{m}^{-3}\right)$ was principally caused by the local emissions. On average, the contributions of local emissions and regional transport to the $\mathrm{PM}_{2.5}$ concentration in Stage 2 were $51 \%$ and $24 \%$, respectively. The impact of regional transport could be qualitatively expressed by specific humidity, which was treated as an indicator of the origin of air masses (Jia et al., 2008). Air masses from the south were usually warmer and wetter than those from the north; thus, the specific humidity averaged over the BTH region was higher in Stage $1\left(1.7 \mathrm{~g} \mathrm{~kg}^{-1}\right)$ than in Stage 2 $\left(1.4 \mathrm{~g} \mathrm{~kg}^{-1}\right.$ ) (Fig. 7b). The evolution of $\mathrm{PM}_{2.5}$ followed the trend of specific humidity well, with a high correlation coefficient of 0.86 .

\subsection{Contributions of each physical/chemical process to variations in $\mathbf{P M}_{2.5}$ concentrations}

Figure $8 \mathrm{a} 1-\mathrm{a} 2$ show the diurnal variations of $\mathrm{PM}_{2.5}$ concentrations averaged over the BTH region during Stage 1 and Stage 2, respectively. The $\mathrm{PM}_{2.5}$ concentration increased by $43.9 \mu \mathrm{g} \mathrm{m}^{-3}$ (from $136.5 \mu \mathrm{g} \mathrm{m}^{-3}$ at 00:00 LST to $180.4 \mu \mathrm{g} \mathrm{m}^{-3}$ at 23:00 LST) during the period of particulate accumulation (Stage 1), but it decreased by $41.5 \mu \mathrm{g} \mathrm{m}^{-3}$ during the period of particulate elimination (Stage 2).

The hourly $\mathrm{PM}_{2.5}$ changes induced by each and all physical/chemical processes during Stage 1 and Stage 2 established using the IPR analysis method are shown in Fig. 8b1b2. During both stages, the dominant sources of surface-layer $\mathrm{PM}_{2.5}$ were EMIS and AERC, whereas the main sinks were TRAN, DIFF, and DRYD. The maximum positive contribution of EMIS could be found during the rush hours (07:00 08:00 and 16:00-19:00 LST; Fig. S3). The maximum negative contributions of TRAN and DIFF appeared at late night (01:00-05:00 LST) and at noon (11:00-14:00 LST), respectively.

To explain the reason for the $24 \mathrm{~h} \mathrm{PM}_{2.5}$ increase during Stage 1 and the $24 \mathrm{~h} \mathrm{PM}_{2.5}$ decrease during Stage 2 (Fig. 8a1-a2), we quantify the contributions of each physi$\mathrm{cal} /$ chemical process to $24 \mathrm{~h} \mathrm{PM}_{2.5}$ changes for both stages 

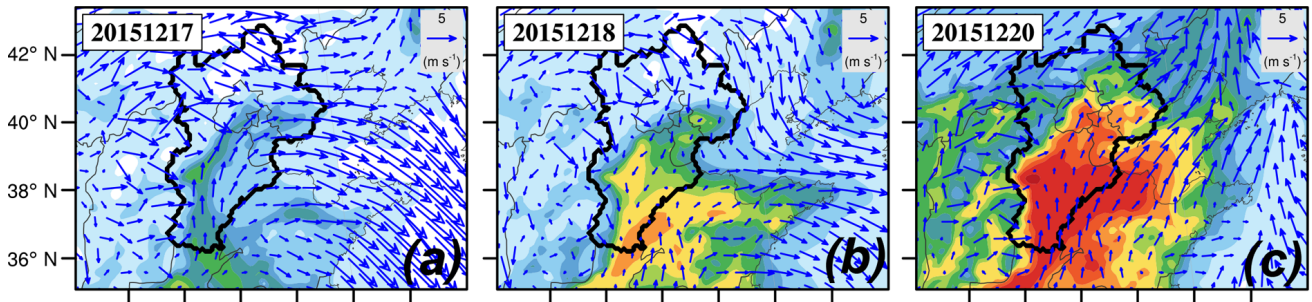

$\left(\mu g m^{\cdot 3}\right)$

600
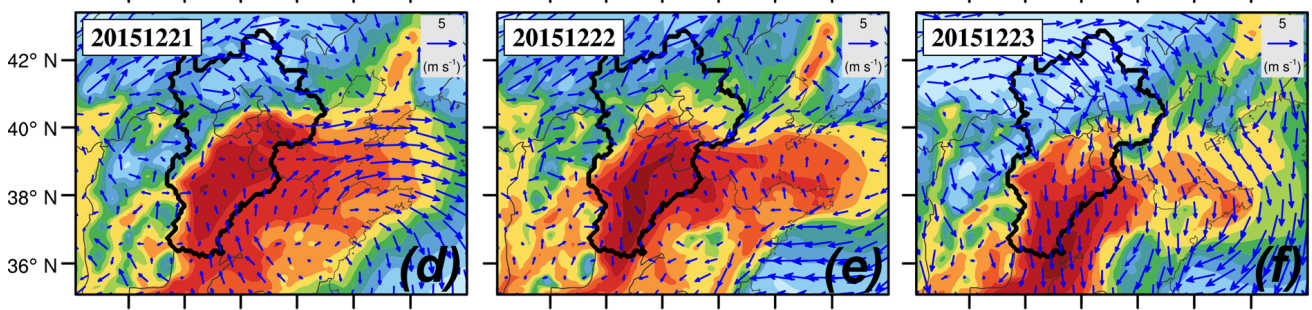

400

300
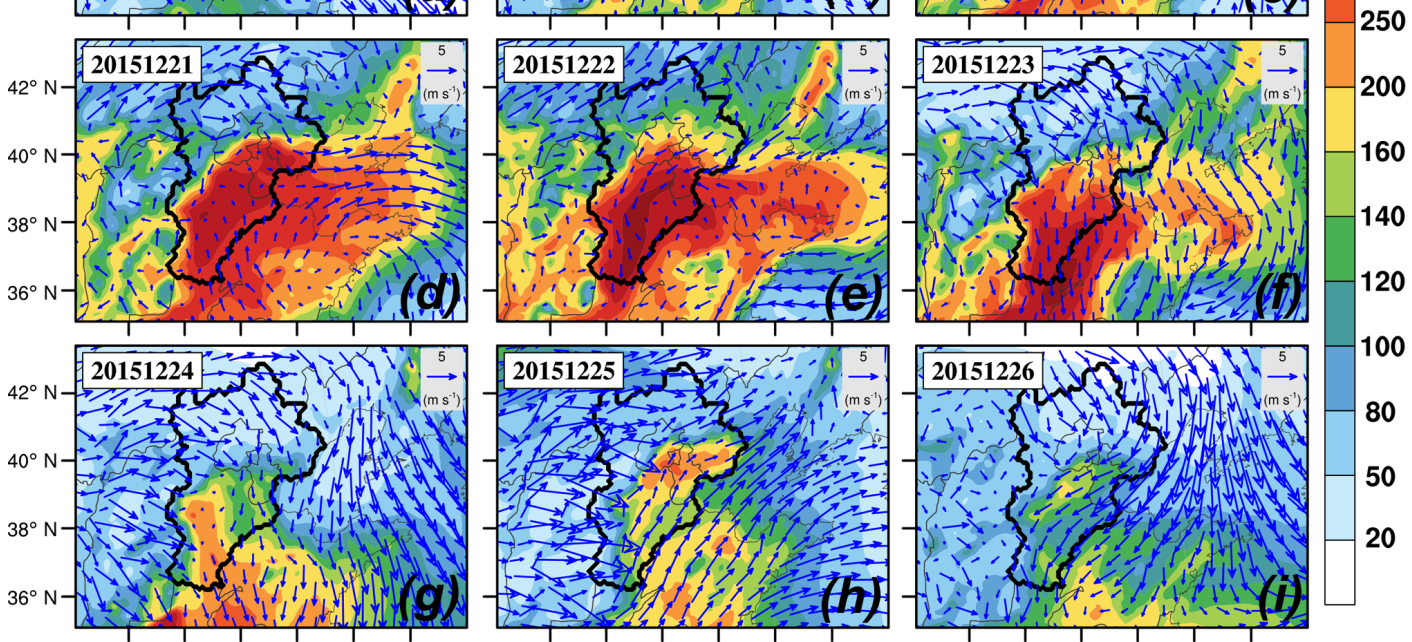

200

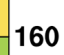

140

120

100

80

50

20
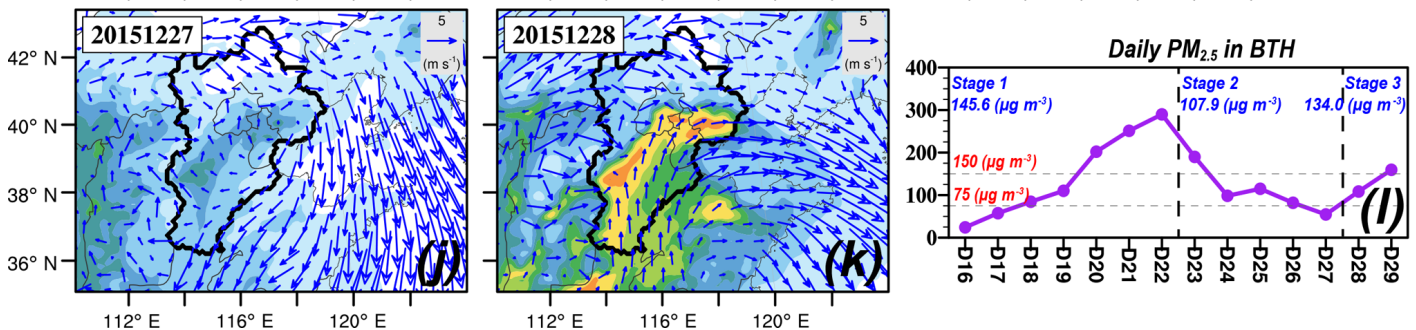

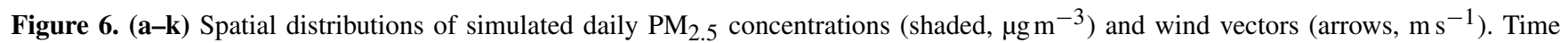
series of simulated daily $\mathrm{PM}_{2.5}$ concentrations averaged over the Beijing-Tianjin-Hebei region are also shown in panel (l).

(Fig. 8c1-c2), which are calculated by integrating the hourly $\mathrm{PM}_{2.5}$ changes induced by each process from 00:00 to 23:00 LST (Fig. 8b1-b2). In WRF-Chem, DRYD is intermingled with vertical diffusion, meaning that changes in the column burden during vertical mixing can be attributed to DRYD (Tao et al., 2015). Following Tao et al. (2015), we define vertical mixing (VMIX) as the sum of DIFF and DRYD. As shown in Fig. 8c1-c2, contributions of the AERC, TRAN, and VMIX processes to the $24 \mathrm{~h} \mathrm{PM}_{2.5}$ changes

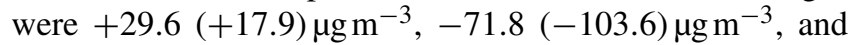
$-177.3(-221.6) \mu^{-3} \mathrm{~m}^{-3}$ for Stage 1 (Stage 2), respectively. Small differences were found for contributions from other processes between Stage 1 and Stage 2 (differences smaller than $5 \mu \mathrm{g} \mathrm{m}^{-3}$ ). Therefore, the $\mathrm{PM}_{2.5}$ increase over the BTH region during the haze formation stage was mainly attributed to strong production by the aerosol chemistry process and weak removal by the advection and vertical mixing processes. On the contrary, during haze elimination stage (Stage 2), more aerosols in the BTH area were transported out of the BTH region, dispersed to the upper atmosphere or subsided to the ground. Furthermore, the dry cold air from the north decreased the specific humidity (as shown in Fig. 7b) in the BTH area, leading to weaker production of secondary aerosols by aerosol chemistry process.

\section{Aerosol radiative effects (ARE) on the haze episode}

Previous studies have demonstrated that aerosol radiative forcing could increase the near-surface $\mathrm{PM}_{2.5}$ concentrations by about $12 \%-29 \%$ (Gao et al., 2015, 2016; Qiu et al., 2017; Zhou et al., 2018). However, the detailed influence mechanisms (i.e., the prominent physical or chemical process responsible for the aerosol radiative impacts on $\mathrm{PM}_{2.5}$ concentrations) are still unclear. In this section, we examine the effects of aerosol radiative forcing on meteorological parameters and $\mathrm{PM}_{2.5}$ levels during the haze episode, with a special focus on the detailed influence mechanism using IPR analysis. 


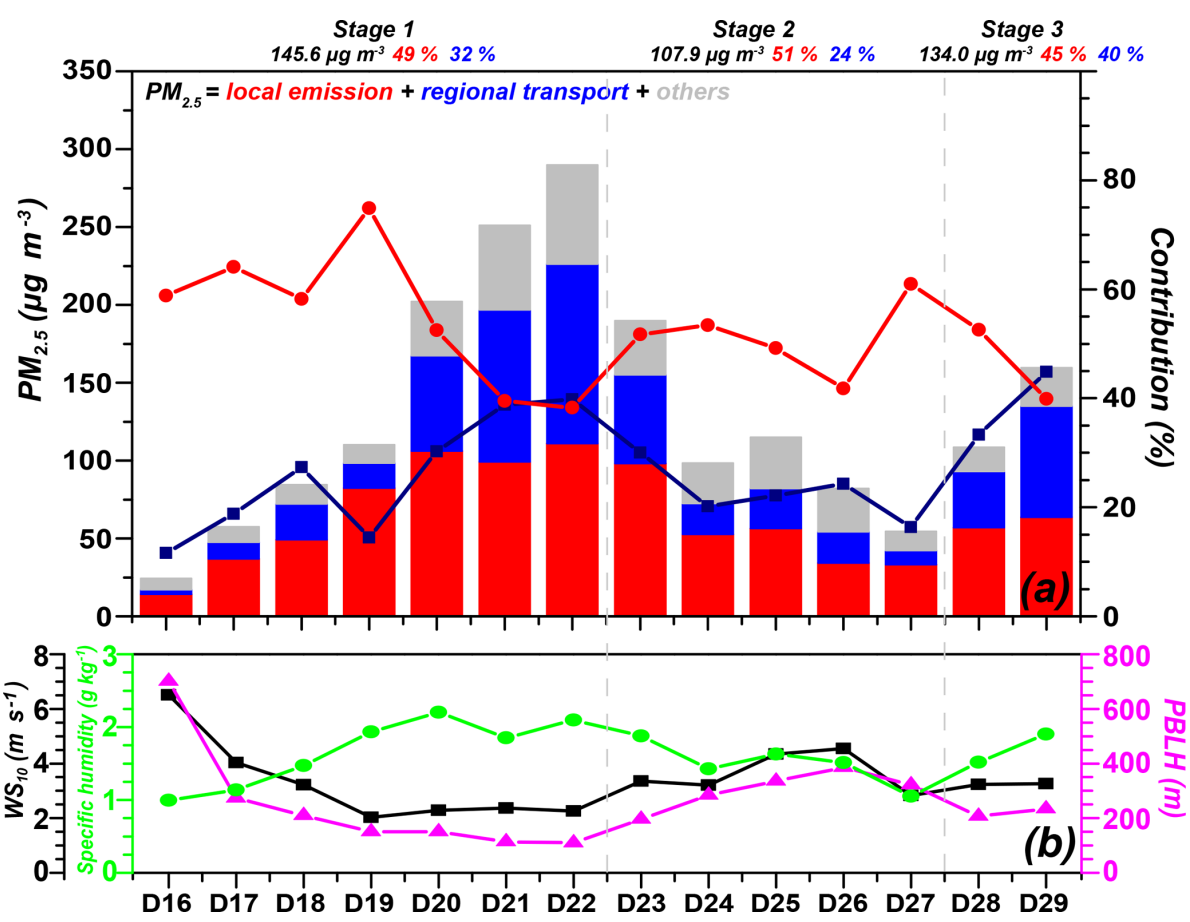

Figure 7. (a) Contributions of local emissions (red) and regional transport (blue) to the near-surface $\mathrm{PM}_{2.5}$ concentrations averaged over the Beijing-Tianjin-Hebei region from 16 to 29 December 2015. The absolute contributions $\left(\mu \mathrm{g} \mathrm{m}^{-3}\right)$ are shown using bars, and the percentage contributions (\%) are shown using lines. The $\mathrm{PM}_{2.5}$ concentration and the percentage contributions averaged over each stage are listed at the top of panel (a). Simulated daily $10 \mathrm{~m}$ wind speed $\left(\mathrm{WS}_{10} ; \mathrm{m} \mathrm{s}^{-1}\right.$; black dotted line), specific humidity ( $\mathrm{g} \mathrm{kg}^{-1}$; green dotted line), and PBLH (m; magenta dotted line) averaged over Beijing-Tianjin-Hebei are also shown in panel (b).

\subsection{Effects of aerosol radiative forcing on meteorological parameters and $\mathbf{P M}_{2.5}$ concentrations}

Figure 9 illustrates the impacts of aerosols on the downward shortwave radiative flux (SW) at the surface (BOT_SW) and in the atmosphere (ATM_SW), calculated by subtracting the model results of NoARE from those of CTL, during Stage 1, Stage 2, and the whole simulation period. Downward SW at the surface decreased strongly when ARE was considered, especially over high aerosol-loading regions during heavily polluted periods. Generally, the shortwave radiation fluxes at the surface averaged over BTH were reduced by $28 \%$ $\left(23.9 \mathrm{~W} \mathrm{~m}^{-2}\right)$ in Stage $1,18 \%\left(16.6 \mathrm{~W} \mathrm{~m}^{-2}\right)$ in Stage 2, and $23 \%\left(19.9 \mathrm{~W} \mathrm{~m}^{-2}\right)$ during the whole simulation period. Contrary to the significant negative effects at the surface, as a result of ARE, the downward SW fluxes in the atmosphere averaged over the BTH region were increased by $65 \%$ $\left(19.1 \mathrm{~W} \mathrm{~m}^{-2}\right)$ in Stage $1,37 \%\left(10.8 \mathrm{~W} \mathrm{~m}^{-2}\right)$ in Stage 2, and $51 \%\left(14.7 \mathrm{~W} \mathrm{~m}^{-2}\right)$ during the whole period.

The impacts of ARE (including aerosol direct and indirect effects) on meteorological parameters and $\mathrm{PM}_{2.5}$ concentrations are analyzed in Fig. 10. Because less SW could reach the ground, near-surface temperature decreased over BTH (Fig. 10a), especially during heavy pollution periods, and the largest decrease was up to $2 \mathrm{~K}$. Meanwhile, the increased SW in the atmosphere warmed the upper air. As a result, a more stable atmosphere was expected. It is known that the atmospheric stability can be exactly characterized by the profile of equivalent potential temperature (EPT) (Bolton, 1980; Zhao et al., 2013; J. Yang et al., 2016). If the EPT rises with height, the atmosphere is stable. As shown in Fig. 10b, the EPT decreased in the lower atmosphere (below $\sim 1000 \mathrm{~m}$ ) with the largest decrease of $3 \mathrm{~K}$ on 22 December, but it increased in the upper atmosphere (above $\sim 1200 \mathrm{~m}$ ). The change in the EPT profile indicated that ARE could lead to a more stable atmosphere, which further weakened vertical movement in the BTH (Fig. 10c). As a result of ARE, the PBLH decreased and the relative humidity in the lower atmosphere increased (Fig. 10d). All of the changes in the meteorological variables were beneficial for $\mathrm{PM}_{2.5}$ accumulation in the lower atmosphere (Fig. 10e). The daily maximum increase in the $\mathrm{PM}_{2.5}$ concentration was $43.2 \mu \mathrm{gm}^{-3}$ due to ARE. It was noticed that ARE had a negative impact on the near-surface $\mathrm{PM}_{2.5}$ concentrations from 23 to 24 December, which could be explained by the fact that absorbing aerosols (i.e., BC) induced anomalous northeasterlies, and then the relatively clean air transported from the northeastern regions to the BTH region (Fig. S4). 

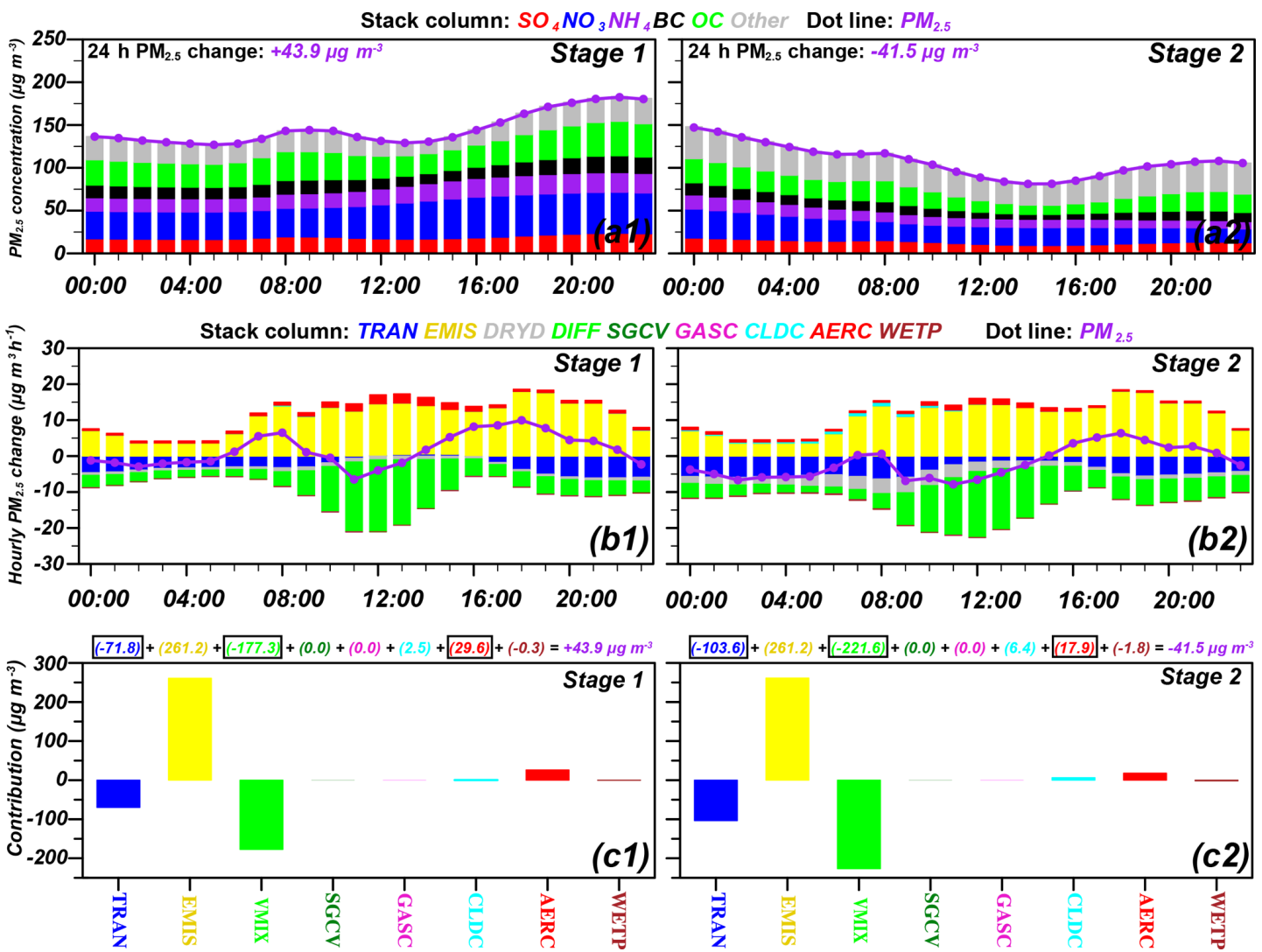

Figure 8. (a1-a2) Diurnal variations of $\mathrm{PM}_{2.5}$ concentrations averaged over Beijing-Tianjin-Hebei during Stage 1 and Stage 2 (purple dotted lines). The colored bars represent different components. The $24 \mathrm{~h}$ change in $\mathrm{PM}_{2.5}$ concentration (23:00 minus 00:00 LST) is also shown in the top-left corner of each panel. (b1-b2) The hourly $\mathrm{PM}_{2.5}$ changes induced by each physical/chemical process using the IPR analysis method (colored bars). The purple dotted lines represent hourly $\mathrm{PM}_{2.5}$ changes induced by all processes, also indicating the differences between current and previous-hour $\mathrm{PM}_{2.5}$ concentrations. (c1-c2) Contributions of each physical/chemical process to $24 \mathrm{~h} \mathrm{PM}_{2.5}$ changes.

\subsection{Influence mechanism of aerosol radiative effects}

As variations in $\mathrm{PM}_{2.5}$ concentrations are directly caused by physical and chemical processes (Zhu et al., 2015), the IPR method is then used to investigate the detailed influence mechanisms (i.e., the prominent physical or chemical processes responsible for the aerosol radiative impacts on haze episodes). Figure 11a-b show the diurnal variations of $\mathrm{PM}_{2.5}$ concentrations in the NoARE and CTL cases averaged over the BTH region in Stage 1. A $24 \mathrm{~h}$ increase of $39.1 \mu \mathrm{g} \mathrm{m}^{-3}$ was simulated in the NoARE case. When aerosol radiative forcing was considered, the $24 \mathrm{~h}$ increase of $\mathrm{PM}_{2.5}$ concentration was $43.9 \mu \mathrm{g} \mathrm{m}^{-3}$. The enhancement of $4.8 \mu \mathrm{g} \mathrm{m}^{-3}$ (12\%) induced by ARE could be mainly attributed to the contributions of the VMIX, TRAN, and AERC processes, as shown in Fig. 11c. The vertical mixing was strongly restrained by ARE; therefore, fewer particles diffused from the surface to the upper layer, resulting in the accumulation of $\mathrm{PM}_{2.5}$ in a lower atmospheric boundary layer. The changes induced by ARE in contributions of the VMIX process exhibited positive values in the lower layers and negative values in the upper layers (Fig. S5a). Generally, the VMIX process contributed $+22.5 \mu \mathrm{g} \mathrm{m}^{-3}$ to the enhancement in the $24 \mathrm{~h}$ $\mathrm{PM}_{2.5}$ increase $\left(+4.8 \mu \mathrm{g} \mathrm{m}^{-3}\right)$ for Stage 1. The TRAN process, however, contributed $-19.6 \mu \mathrm{g} \mathrm{m}^{-3}$. Constrained vertical mixing due to ARE could increase aerosol precursors and water vapor in the thin boundary layer to enhance the formation of secondary particles. Generally, the AERC process contributed $+1.2 \mu \mathrm{g} \mathrm{m}^{-3}$. The positive contribution of AERC was mainly distributed over the highly polluted regions in the BTH area (Fig. S5b). Specifically, the average changes in the concentrations of $\mathrm{SO}_{4}^{2-}, \mathrm{NO}_{3}^{-}$, and $\mathrm{NH}_{4}^{+}$during the daytime from 11:00 to 17:00 LST in Stage 1 were $-0.5,+1.3$, and $+0.8 \mu \mathrm{g} \mathrm{m}{ }^{-3}$, respectively. The decreased near-surface temperature caused by ARE may suppress the chemical formation of $\mathrm{SO}_{4}^{2-}$. Generally, the total contribution of the VMIX, TRAN, and AERC processes to the change in the $24 \mathrm{~h} \mathrm{PM}_{2.5}$ increase caused by ARE was $+4.1 \mu \mathrm{g} \mathrm{m}^{-3}$, and the restrained vertical mixing could be the primary reason for the near-surface $\mathrm{PM}_{2.5}$ increase when aerosol radiative forcing was considered. 

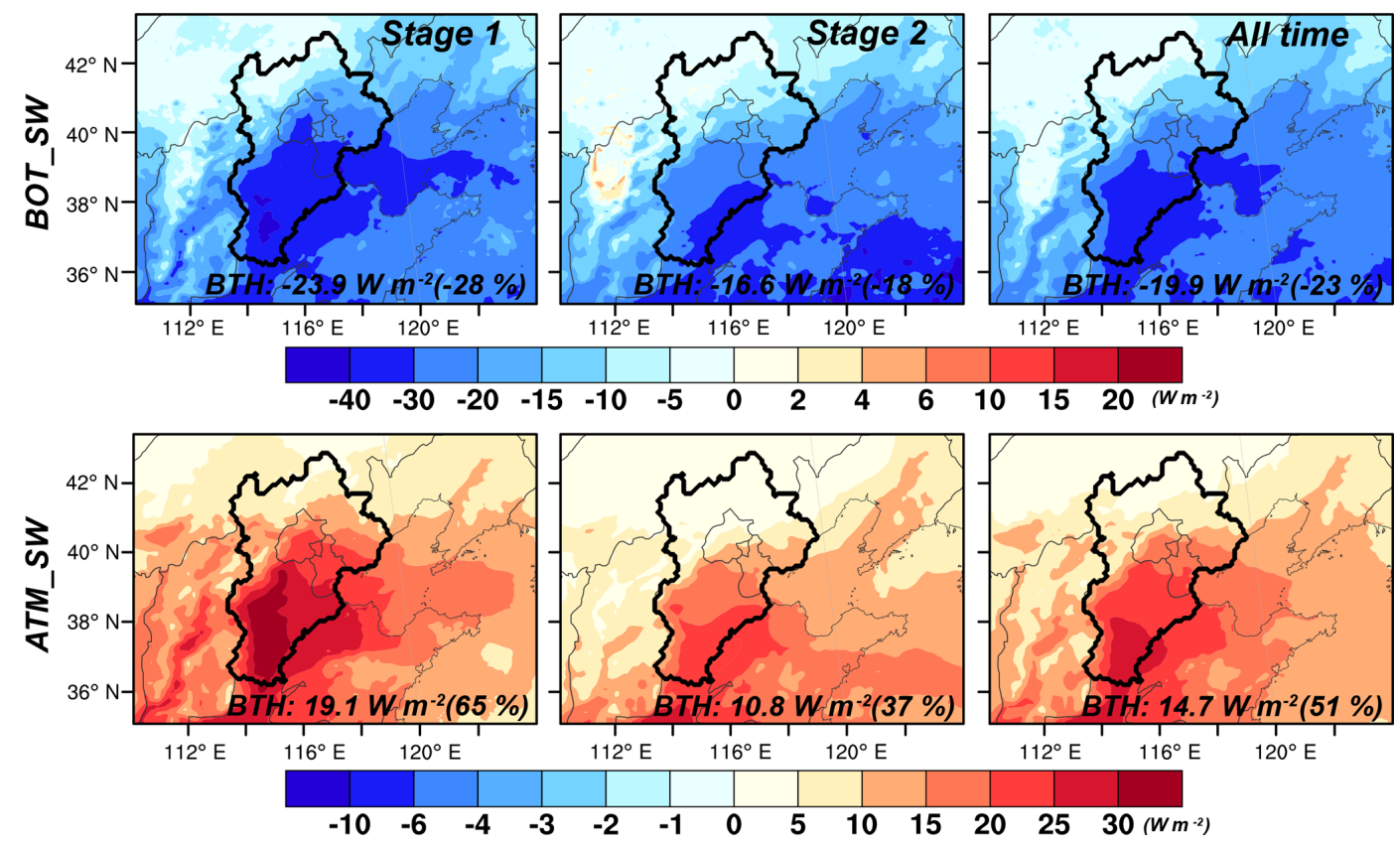

Figure 9. The differences in simulated all-sky radiative forcing $\left(\mathrm{W} \mathrm{m}^{-2}\right)$ between the CTL and NoARE cases (CTL minus NoARE) averaged over Stage 1, Stage 2, and the whole simulation period. "BOT_SW" and "ATM_SW" denote the downward shortwave radiative flux at the surface and in the atmosphere, respectively. The calculated differences in the simulated radiative forcing averaged over Beijing-TianjinHebei for each stage are also shown at the bottom of each panel.

Figure 12a shows the vertical profiles of the $24 \mathrm{~h}$ increases in the $\mathrm{PM}_{2.5}$ concentrations (23:00 minus 00:00 LST) averaged over the BTH region during Stage 1 in the CTL and NoARE cases. Below $\sim 300 \mathrm{~m}$ (between L01 and L04), the $24 \mathrm{~h}$ increase simulated by CTL was larger than that in NoARE, which could be mainly explained by the fact that the positive contributions of VMIX exceeded the negative contributions of TRAN in the lower atmosphere when aerosol radiative effect was considered (Fig. 12b). However, in the upper layers (from 300 to $2000 \mathrm{~m}$ ), aerosol radiative forcing weakened the $24 \mathrm{~h} \mathrm{PM}_{2.5}$ increase during Stage 1. When the aerosol radiative effect was considered, less particulate matter, precursors and water vapor were diffused from the surface to the upper layers; therefore, fewer particles were formed in the upper layers. Despite the positive contributions of TRAN, the net contributions of VMIX, TRAN, and AERC to $\mathrm{PM}_{2.5}$ changes caused by ARE in the upper atmosphere were negative.

\section{Conclusions and discussions}

In this study, an online coupled mesoscale meteorologychemistry model (WRF-Chem) with an improved integrated process rate (IPR) analysis (i.e., process analysis) scheme was applied to investigate the formation and evolution mechanisms of a severe haze episode that occurred in the BTH region from 16 to 29 December 2015. Sensitivity experiments were conducted to examine the contributions of local emissions and regional transport to the $\mathrm{PM}_{2.5}$ concentrations during the haze event, while IPR analysis was used to quantify the contributions of each physical/chemical process to the variation in $\mathrm{PM}_{2.5}$ concentration. The impacts of aerosol radiative forcing (including direct and indirect effects) were also quantified, with a special focus on the detailed influence mechanism (i.e., prominent process responsible for the aerosol radiative impacts on the haze event). An integrated comparison between observations and simulations demonstrated good performance for both meteorological and chemical variables, indicating that the WRF-Chem model has the capability to reproduce the haze episode.

Spatial-temporal evolutions of the near-surface $\mathrm{PM}_{2.5}$ concentration, and the contributions of local emissions and regional transport to the severe haze event in $\mathrm{BTH}$, were first analyzed. During the aerosol accumulation stage (16-22 December, Stage 1), the daily $\mathrm{PM}_{2.5}$ concentration in the $\mathrm{BTH}$ region experienced a consistent increase, with the mean value of $145.6 \mu \mathrm{g} \mathrm{m}^{-3}$. The contributions of local emissions and regional transport to the $\mathrm{PM}_{2.5}$ concentration were comparable ( $49 \%$ and $32 \%$, respectively), meaning that the combined effect resulted in the high $\mathrm{PM}_{2.5}$ concentration in the BTH area. During the aerosol dispersion stage (23-27 December, Stage 2), the average $\mathrm{PM}_{2.5}$ concentration in BTH was $107.9 \mathrm{\mu g} \mathrm{m}^{-3}$. The contributions of local emissions and regional transport were $51 \%$ and $24 \%$, respectively. Therefore, the relatively high $\mathrm{PM}_{2.5}$ concentration during Stage 2 was principally caused by local emissions. Over the period 

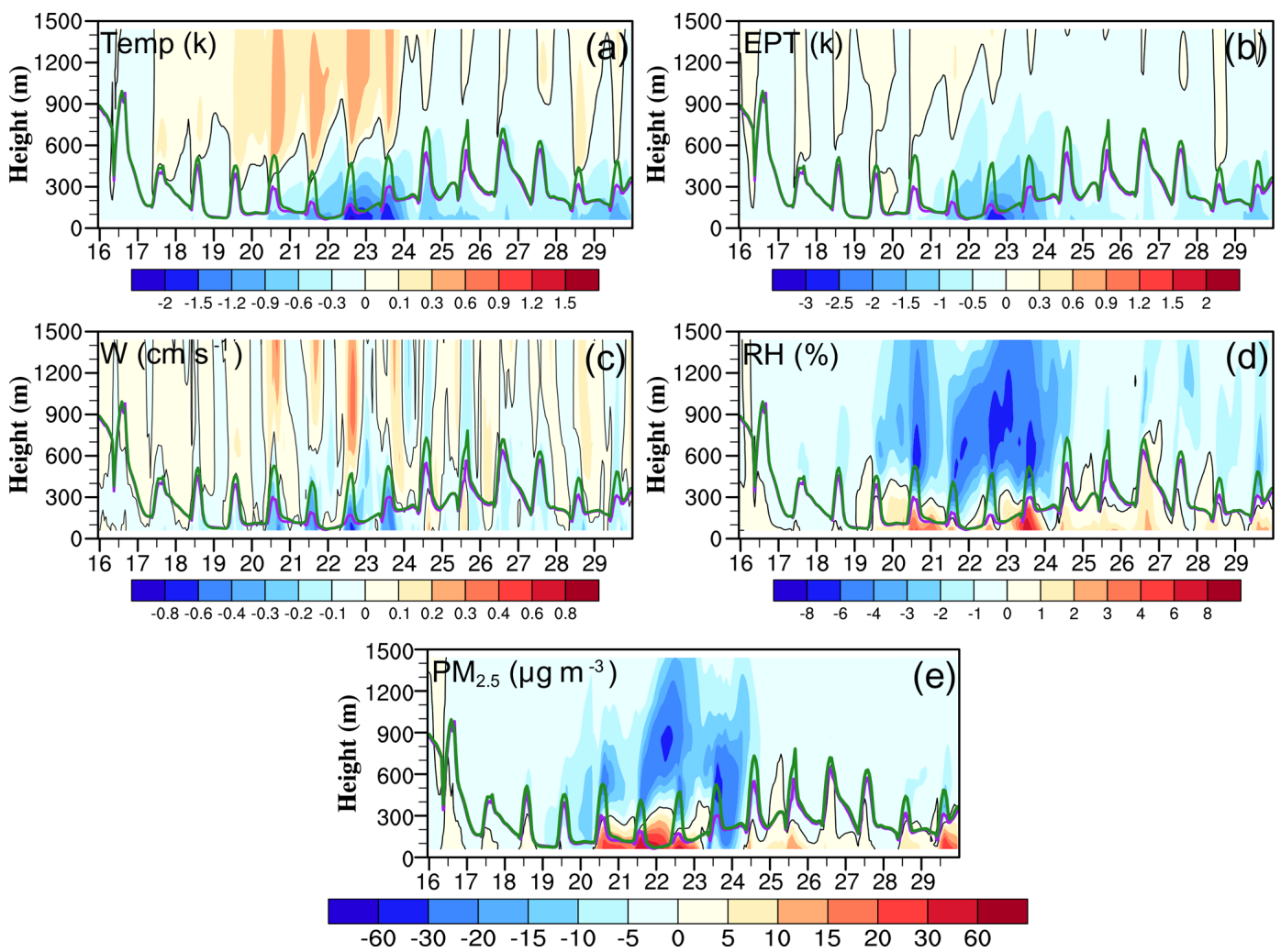

Figure 10. Time series of differences in (a) temperature $(\mathrm{K}),(\mathbf{b})$ equivalent potential temperature $(\mathrm{K})$, (c) vertical wind speed ( $\mathrm{cm} \mathrm{s}^{-1}$ ), (d) relative humidity (\%), and (e) $\mathrm{PM}_{2.5}$ concentration $\left(\mu \mathrm{g} \mathrm{m}^{-3}\right)$ between the CTL and NoARE cases (CTL minus NoARE) averaged over the Beijing-Tianjin-Hebei region. The purple and green lines denote the simulated PBLH in the CTL and NoARE cases, respectively. The black line represents the zero contour line.

from 28 to 29 December (Stage 3), another haze event was formed and developed.

IPR analysis was then used to explain the reason for the $\mathrm{PM}_{2.5}$ increase during Stage 1 and the decrease during Stage 2, by quantifying the contributions of each phys$\mathrm{ical} /$ chemical process to variations in $\mathrm{PM}_{2.5}$ concentration. During both stages, the dominant sources were emissions (EMIS) and aerosol chemistry (AERC), whereas the main sinks were turbulent diffusion (DIFF), advection (TRAN), and dry deposition (DRYD). The $\mathrm{PM}_{2.5}$ concentration increased by $43.9 \mathrm{\mu g} \mathrm{m}^{-3}$ (23:00 minus 00:00 LST) during Stage 1 , but it decreased by $41.5 \mu^{-3}$ m during Stage 2 . The contributions of AERC, TRAN, and VMIX (vertical mixing, the sum of DRYD and DIFF) to the $24 \mathrm{~h} \mathrm{PM}_{2.5}$ changes were $+29.6(+17.9) \mu \mathrm{g} \mathrm{m}^{-3},-71.8(-103.6) \mu \mathrm{g} \mathrm{m}^{-3}$ and -177.3 $(-221.6) \mu \mathrm{g} \mathrm{m}^{-3}$ for Stage 1 (Stage 2), respectively. Small differences in the contributions from other processes were found between Stage 1 and Stage 2. Therefore, the $\mathrm{PM}_{2.5}$ increase over the BTH region during the haze formation stage was attributed to strong production by aerosol chemistry process and weak removal by advection and vertical mixing processes.
When aerosol radiative forcing was considered, the equivalent potential temperature decreased in the lower layers but increased in the upper layers, leading to a more stable atmosphere. Meanwhile, the decreased PBLH and increased relative humidity were also beneficial for $\mathrm{PM}_{2.5}$ accumulation. The daily maximum increase of the near-surface $\mathrm{PM}_{2.5}$ concentration in the BTH region was $43.2 \mu \mathrm{g} \mathrm{m}^{-3}$. The IPR method was also used to investigate the detailed influence mechanism of aerosol radiative effects. When aerosol radiative feedback was considered, the $24 \mathrm{~h} \mathrm{PM}_{2.5}$ increase was enhanced by $4.8 \mathrm{\mu g} \mathrm{m}^{-3}(12 \%)$ during Stage 1 , which could be mainly attributed to the contributions of VMIX $\left(+22.5 \mu \mathrm{g} \mathrm{m}^{-3}\right)$, TRAN $\left(-19.6 \mu \mathrm{g} \mathrm{m}^{-3}\right)$, and AERC $\left(+1.2 \mu \mathrm{g} \mathrm{m}^{-3}\right)$. The restrained vertical mixing could be the primary reason for near-surface $\mathrm{PM}_{2.5}$ increase when aerosol radiative forcing was considered.

There are some limitations to this work. The uncertainty of the MIX anthropogenic emission inventory, the lack of secondary organic aerosols, and the missing mechanisms of some heterogeneous reactions may result in large uncertainties in the final simulation results, especially the predicted aerosol chemical compositions, such as $\mathrm{SO}_{4}^{2-}, \mathrm{NO}_{3}^{-}$, and $\mathrm{NH}_{4}^{+}$. The biases in simulated concentrations of $\mathrm{SO}_{4}^{2-}$, 

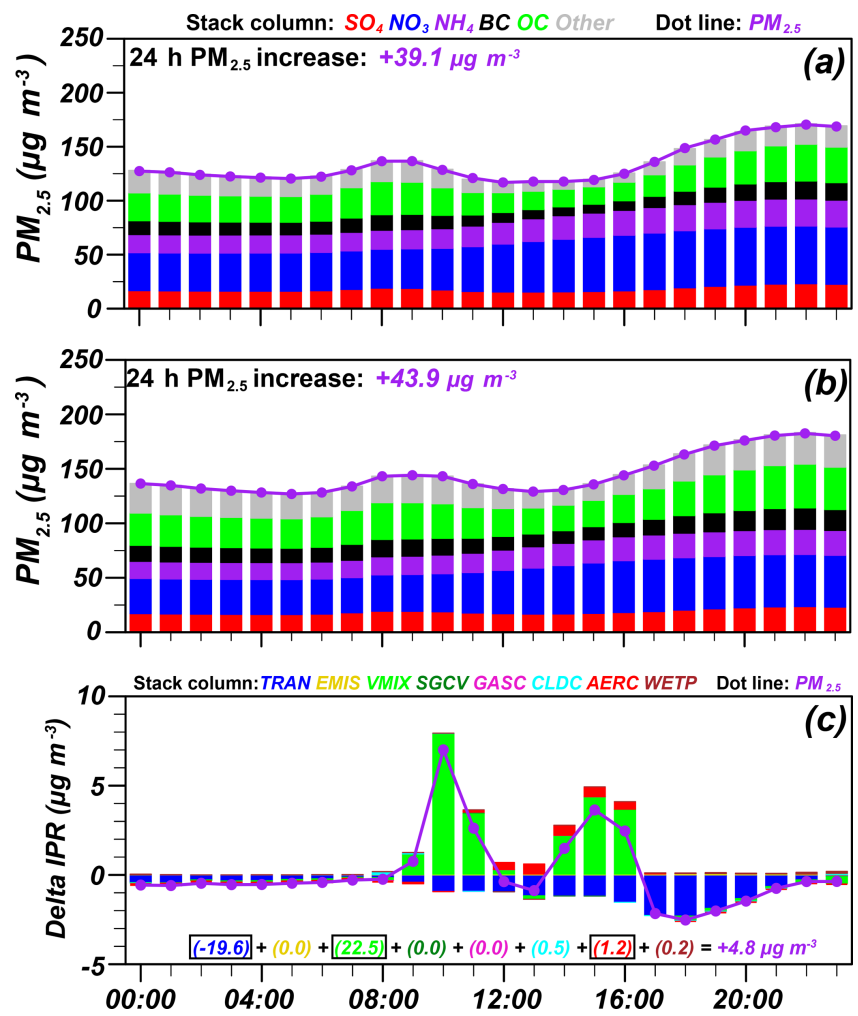

Figure 11. Diurnal variations of the near-surface $\mathrm{PM}_{2.5}$ concentrations in the (a) NoARE and (b) CTL simulations averaged over the Beijing-Tianjin-Hebei region during Stage 1 (purple dotted lines). The colored bars represent different components. The $24 \mathrm{~h}$ increase in $\mathrm{PM}_{2.5}$ concentration (23:00 minus 00:00 LST) is also shown in the top-left corner of each panel. (c) Differences in hourly IPRs caused by aerosol radiative forcing (CTL minus NoARE). The numbers listed in panel (c) represent the contributions of each process to the change in the $24 \mathrm{~h} \mathrm{PM}_{2.5}$ increase caused by aerosol radiative forcing.

$\mathrm{NO}_{3}^{-}$, and $\mathrm{NH}_{4}^{+}$may have impacts on the contributions of the AERC and CLDC processes to the air pollution variation. Uncertainties should be quantitatively analyzed in future studies. Furthermore, conclusions draw from a case study in the BTH region cannot represent a full view of the underlying mechanisms of haze formation and elimination. A better understanding will be attained by conducting multiplecase simulations in the future. Furthermore, an anomalous northeasterly induced by absorbing aerosols was observed, leading to a decrease in the near-surface $\mathrm{PM}_{2.5}$ concentrations from 23 to 24 December 2015 in the BTH area, which was different from previous studies that reported that lightabsorbing aerosols could worsen air quality (Li et al., 2016; Huang et al., 2018; Gao et al., 2018). More experiments should be designed in the future to examine the changes in atmospheric thermal and atmospheric dynamic caused by absorbing aerosol radiative forcing and their impacts on haze episodes.
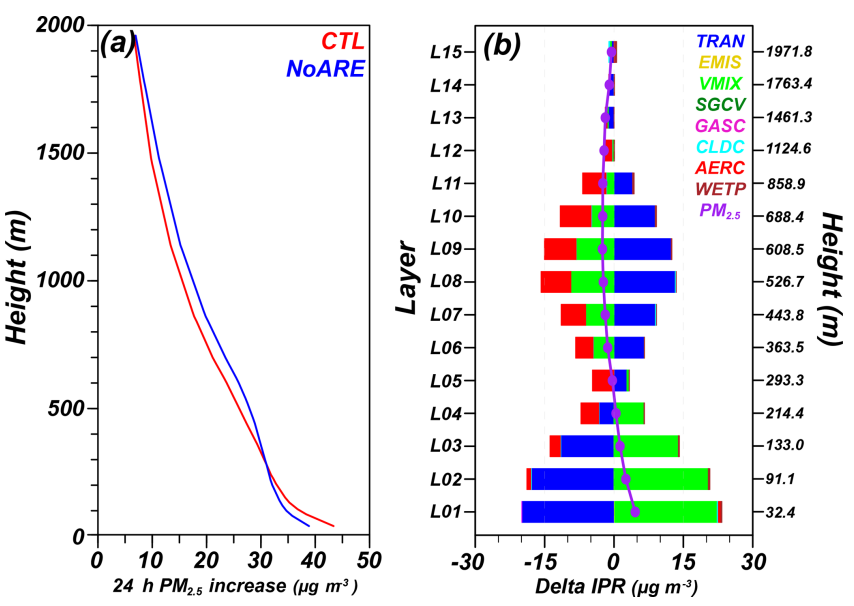

Figure 12. (a) Vertical profiles of the $24 \mathrm{~h}$ increases in $\mathrm{PM}_{2.5}$ concentrations (23:00 minus 00:00 LST) averaged over BeijingTianjin-Hebei during Stage 1 in the CTL and NoARE cases. (b) Vertical profiles of the differences in the $24 \mathrm{~h} \mathrm{PM}_{2.5}$ increases caused by the aerosol radiative effect (CTL minus NoARE, purple dotted line), and the contributions of each physical/chemical process (colored bars)

As Zheng et al. (2018) pointed out, the $\mathrm{PM}_{2.5}$ concentration in China has been decreasing in recent years; however, this decrease in fine particulate matter could stimulate ozone production (K. Li et al., 2019; Zhu et al., 2019). Multipollutant mixture may be a hot topic in the future, and IPR analysis could be a useful method to provide a quantitative analysis of the formation mechanism of complex air pollution, including figuring out the major physical/chemical process behind these events. Meanwhile, significant differences between model predictions (e.g., $\mathrm{O}_{3}$ and $\mathrm{PM}_{2.5}$ ) are found among current multi-scale air quality models (L. Chen et al., 2019; J. Li et al., 2019), even though the same inputs are used. These different performances can be associated with the differences in model formulations, including parameterizations and numerical methods (Carmichael et al., 2008). In order to acquire a quantitative attribution of the cause of differences between simulation results, a process analysis method should be developed and implemented in these models, and the use of IPR analysis would make it easier to draw conclusions about the fundamental problems that cause the differences between model predictions.

Data availability. Observational datasets and simulation results are available upon request from the corresponding author (hongliao@nuist.edu.cn).

Supplement. The supplement related to this article is available online at: https://doi.org/10.5194/acp-19-10845-2019-supplement. 
Author contributions. HL and LC conceived the study and designed the experiments. LC and JZ performed the simulations and carried out the data analysis. YG, MZ, YQ, ZL, NL, and YW provided useful comments on the paper. LC prepared the paper with contributions from all the co-authors.

Competing interests. The authors declare that they have no conflict of interest.

Special issue statement. This article is part of the special issue "Regional transport and transformation of air pollution in eastern China". It is not associated with a conference.

Acknowledgements. The authors thank the Campaign on Atmospheric Aerosol Research network of China (CARE-China) for providing measurements on aerosol chemical compositions to evaluate the model performance. Many thanks to the anonymous reviewers for their helpful comments that improved our paper.

Financial support. This study was supported by the National Natural Science Foundation of China (grant nos. 91544219 and 91744311), the University Natural Science Research Foundation of Jiangsu Province (grant no. 18KJB170012), the China Postdoctoral Science Foundation (grant no. 2019M650117), and the Startup Foundation for Introducing Talent of NUIST (grant no. 2018r007).

Review statement. This paper was edited by Zhanqing Li and reviewed by three anonymous referees.

\section{References}

Ackermann, I. J., Hass, H., Memmesheimer, M., Ebel, A., Binkowski, F. S., and Shankar, U. M. A.: Modal aerosol dynamics model for Europe: Development and first applications, Atmos. Environ., 32, 2981-2999, https://doi.org/10.1016/S13522310(98)00006-5, 1998.

Barnard, J. C., Fast, J. D., Paredes-Miranda, G., Arnott, W. P., and Laskin, A.: Technical Note: Evaluation of the WRF-Chem "Aerosol Chemical to Aerosol Optical Properties" Module using data from the MILAGRO campaign, Atmos. Chem. Phys., 10, 7325-7340, https://doi.org/10.5194/acp-10-7325-2010, 2010.

Bolton, D.: The computation of equivalent potential temperature. Mon. Weather Rev., 108, 1046-1053, https://doi.org/10.1175/15200493(1980)108<1046:TCOEPT>2.0.CO;2, 1980.

Boylan, J. W. and Russell, A. G.: PM and light extinction model performance metrics, goals, and criteria for threedimensional air quality models, Atmos. Environ., 40, 49464959, https://doi.org/10.1016/j.atmosenv.2005.09.087, 2006.

Carmichael, G., Sakurai, T., Streets, D., Hozumi, Y., Ueda, H., Park, S., Fung, C., Han, Z., Kajino, M., and Engardt, M.: MICS-Asia II: The model intercomparison study for Asia Phase II methodol- ogy and overview of findings, Atmos. Environ., 42, 3468-3490, https://doi.org/10.1016/j.atmosenv.2007.04.007, 2008.

Chen, D., Liu, Z., Fast, J., and Ban, J.: Simulations of sulfatenitrate-ammonium (SNA) aerosols during the extreme haze events over northern China in October 2014, Atmos. Chem. Phys., 16, 10707-10724, https://doi.org/10.5194/acp-16-107072016, 2016.

Chen, J., Li, Z., Lv, M., Wang, Y., Wang, W., Zhang, Y., Wang, H., Yan, X., Sun, Y., and Cribb, M.: Aerosol hygroscopic growth, contributing factors, and impact on haze events in a severely polluted region in northern China, Atmos. Chem. Phys., 19, 13271342, https://doi.org/10.5194/acp-19-1327-2019, 2019.

Chen, L., Zhang, M., Zhu, J., Wang, Y., and Skorokhod, A.: Modeling Impacts of Urbanization and Urban Heat Island Mitigation on Boundary Layer Meteorology and Air Quality in Beijing Under Different Weather Conditions, J. Geophys. Res.-Atmos., 123, 4323-4344, https://doi.org/10.1002/2017jd027501, 2018.

Chen, L., Gao, Y., Zhang, M., Fu, J. S., Zhu, J., Liao, H., Li, J., Huang, K., Ge, B., Wang, X., LAM, Y. F., Lin, C. Y., Itahashi, S., Nagashima, T., Kajino, M., Yamaji, K., Wang, Z., and Kurokawa, J.-I.: MICS-Asia III: Multi-model comparison and evaluation of aerosol over East Asia, Atmos. Chem. Phys. Discuss., https://doi.org/10.5194/acp-2018-1346, in review, 2019.

Ding, A. J., Huang, X., Nie, W., Sun, J. N., Kerminen, V. M., Petäjä, T., Su, H., Cheng, Y. F., Yang, X. Q., Wang, M. H., Chi, X. G., Wang, J. P., Virkkula, A., Guo, W. D., Yuan, J., Wang, S. Y., Zhang, R. J., Wu, Y. F., Song, Y., Zhu, T., Zilitinkevich, S., Kulmala, M., and Fu, C. B.: Enhanced haze pollution by black carbon in megacities in China, Geophys. Res. Lett., 43, 2873-2879, https://doi.org/10.1002/2016gl067745, 2016.

Emmons, L. K., Walters, S., Hess, P. G., Lamarque, J.-F., Pfister, G. G., Fillmore, D., Granier, C., Guenther, A., Kinnison, D., Laepple, T., Orlando, J., Tie, X., Tyndall, G., Wiedinmyer, C., Baughcum, S. L., and Kloster, S.: Description and evaluation of the Model for Ozone and Related chemical Tracers, version 4 (MOZART-4), Geosci. Model Dev., 3, 43-67, https://doi.org/10.5194/gmd-3-43-2010, 2010.

Gao, J., Zhu, B., Xiao, H., Kang, H., Pan, C., Wang, D., and Wang, H.: Effects of black carbon and boundary layer interaction on surface ozone in Nanjing, China, Atmos. Chem. Phys., 18, 70817094, https://doi.org/10.5194/acp-18-7081-2018, 2018.

Gao, M., Carmichael, G. R., Wang, Y., Saide, P. E., Yu, M., Xin, J., Liu, Z., and Wang, Z.: Modeling study of the 2010 regional haze event in the North China Plain, Atmos. Chem. Phys., 16, 1673-1691, https://doi.org/10.5194/acp-16-1673-2016, 2016.

Gao, Y., Zhang, M., Liu, Z., Wang, L., Wang, P., Xia, X., Tao, M., and Zhu, L.: Modeling the feedback between aerosol and meteorological variables in the atmospheric boundary layer during a severe fog-haze event over the North China Plain, Atmos. Chem. Phys., 15, 4279-4295, https://doi.org/10.5194/acp15-4279-2015, 2015.

Gipson, G. L.: Science algorithms of the EPA Models-3 community multiscale air quality (CMAQ) modeling system: Chapter 16, process analysis, edited by: Byun, D. W. and Ching, J. K. S., Reported No. EPA/600/R-99/030, U.S. Environmental Protection Agency, Office of Research and Development, Washington, D.C., 1999.

Gonçalves, M., Jiménez-Guerrero, P., and Baldasano, J. M.: Contribution of atmospheric processes affecting the dynamics of air 
pollution in South-Western Europe during a typical summertime photochemical episode, Atmos. Chem. Phys., 9, 849-864, https://doi.org/10.5194/acp-9-849-2009, 2009.

Gong, S. L., Barrie, L. A., and Blanchet, J. P.: Modeling sea-salt aerosols in the atmosphere: 1. Model development, J. Geophys. Res.-Atmos., 102, 3805-3818, https://doi.org/10.1029/96jd02953, 1997.

Grell, G. A., Peckham, S. E., Schmitz, R., McKeen, S. A., Frost, G., Skamarock, W. C., and Eder, B.: Fully coupled "online" chemistry within the WRF model, Atmos. Environ., 39, 6957-6975, https://doi.org/10.1016/j.atmosenv.2005.04.027, 2005.

$\mathrm{Gu}$, Y.-X. and Liao, H.: Response of fine particulate matter to reductions in anthropogenic emissions in Beijing during the 2014 Asia-Pacific Economic Cooperation summit, Atmos. Ocean. Sci. Lett., 9, 411-419, https://doi.org/10.1080/16742834.2016.1230465, 2016.

Guenther, A., Karl, T., Harley, P., Wiedinmyer, C., Palmer, P. I., and Geron, C.: Estimates of global terrestrial isoprene emissions using MEGAN (Model of Emissions of Gases and Aerosols from Nature), Atmos. Chem. Phys., 6, 3181-3210, https://doi.org/10.5194/acp-6-3181-2006, 2006.

Guo, H., Cheng, T., Gu, X., Wang, Y., Chen, H., Bao, F., Shi, S., Xu, B., Wang, W., Zuo, X., Zhang, X., and Meng, C.: Assessment of $\mathrm{PM}_{2.5}$ concentrations and exposure throughout China using ground observations, Sci. Total Environ., 601-602, 1024-1030, https://doi.org/10.1016/j.scitotenv.2017.05.263, 2017.

Han, T., Liu, X., Zhang, Y., Qu, Y., Zeng, L., Hu, M., and Zhu, T.: Role of secondary aerosols in haze formation in summer in the Megacity Beijing, J. Environ. Sci., 31, 51-60, https://doi.org/10.1016/j.jes.2014.08.026, 2015.

Han, X., Zhang, M., Gao, J., Wang, S., and Chai, F.: Modeling analysis of the seasonal characteristics of haze formation in Beijing, Atmos. Chem. Phys., 14, 10231-10248, https://doi.org/10.5194/acp-14-10231-2014, 2014.

Hu, J., Zhang, H., Chen, S., Ying, Q., Wiedinmyer, C., Vandenberghe, F., and Kleeman, M.: Identifying $\mathrm{PM}_{2.5}$ and $\mathrm{PM}_{0.1}$ Sources for Epidemiological Studies in California, Environ. Sci. Technol., 48, 4980-4990, https://doi.org/10.1021/es404810z, 2014.

Huang, R. J., Zhang, Y., Bozzetti, C., Ho, K. F., Cao, J. J., Han, Y., Daellenbach, K. R., Slowik, J. G., Platt, S. M., Canonaco, F., Zotter, P., Wolf, R., Pieber, S. M., Bruns, E. A., Crippa, M., Ciarelli, G., Piazzalunga, A., Schwikowski, M., Abbaszade, G., SchnelleKreis, J., Zimmermann, R., An, Z., Szidat, S., Baltensperger, U., El Haddad, I., and Prevot, A. S.: High secondary aerosol contribution to particulate pollution during haze events in China, Nature, 514, 218-222, https://doi.org/10.1038/nature13774, 2014.

Huang, X., Song, Y., Zhao, C., Li, M., Zhu, T., Zhang, Q., and Zhang, X.: Pathways of sulfate enhancement by natural and anthropogenic mineral aerosols in China, J. Geophys. Res.-Atmos., 119, 14165-14179, https://doi.org/10.1002/2014JD022301, 2014.

Huang, X., Liu, Z., Liu, J., Hu, B., Wen, T., Tang, G., Zhang, J., Wu, F., Ji, D., Wang, L., and Wang, Y.: Chemical characterization and source identification of $\mathrm{PM}_{2.5}$ at multiple sites in the BeijingTianjin-Hebei region, China, Atmos. Chem. Phys., 17, 1294112962, https://doi.org/10.5194/acp-17-12941-2017, 2017.

Huang, X., Wang, Z., and Ding, A.: Impact of Aerosol-PBL Interaction on Haze Pollution: Multiyear Observational Evi- dences in North China, Geophys. Res. Lett., 45, 8596-8603, https://doi.org/10.1029/2018gl079239, 2018.

Huang, Y., Dickinson, R. E., and Chameides, W. L.: Impact of aerosol indirect effect on surface temperature over East Asia, P. Natl. Acad. Sci. USA, 103, 4371-4376, https://doi.org/10.1073/pnas.0504428103, 2006.

IPCC: Climate Change 2013: The Physical Science Basis: Summary for Policymakers, Cambridge, UK, 2013.

Jia, Y., Rahn, K. A., He, K., Wen, T., and Wang, Y.: A novel technique for quantifying the regional component of urban aerosol solely from its sawtooth cycles, J. Geophys. Res., 113, 60896098, https://doi.org/10.1029/2008jd010389, 2008.

Jiang, C., Wang, H., Zhao, T., Li, T., and Che, H.: Modeling study of $\mathrm{PM}_{2.5}$ pollutant transport across cities in China's Jing-JinJi region during a severe haze episode in December 2013, Atmos. Chem. Phys., 15, 5803-5814, https://doi.org/10.5194/acp15-5803-2015, 2015.

Jiang, F., Zhou, P., Liu, Q., Wang, T., Zhuang, B., and Wang, X.: Modeling tropospheric ozone formation over East China in springtime, J. Atmos. Chem., 69, 303-319, https://doi.org/10.1007/s10874-012-9244-3, 2012.

Jiang, H., Liao, H., Pye, H. O. T., Wu, S., Mickley, L. J., Seinfeld, J. H., and Zhang, X. Y.: Projected effect of 2000-2050 changes in climate and emissions on aerosol levels in China and associated transboundary transport, Atmos. Chem. Phys., 13, 7937-7960, https://doi.org/10.5194/acp-13-7937-2013, 2013.

Jiang, Z., Huo, F., Ma, H., Song, J., and Dai, A.: Impact of Chinese Urbanization and Aerosol Emissions on the East Asian Summer Monsoon, J. Climate, 30, 1019-1039, https://doi.org/10.1175/jcli-d-15-0593.1, 2017.

Kang, H., Zhu, B., Gao, J., He, Y., Wang, H., Su, J., Pan, C., Zhu, T., and Yu, B.: Potential impacts of cold frontal passage on air quality over the Yangtze River Delta, China, Atmos. Chem. Phys., 19, 3673-3685, https://doi.org/10.5194/acp-19-3673-2019, 2019.

Khiem, M., Ooka, R., Hayami, H., Yoshikado, H., Huang, H., and Kawamoto, Y.: Process analysis of ozone formation under different weather conditions over the Kanto region of Japan using the MM5/CMAQ modelling system, Atmos. Environ., 44, 44634473, https://doi.org/10.1016/j.atmosenv.2010.07.038, 2010.

Kong, S., Li, X., Li, L., Yin, Y., Chen, K., Yuan, L., Zhang, Y., Shan, Y., and Ji, Y.: Variation of polycyclic aromatic hydrocarbons in atmospheric $\mathrm{PM}_{2.5}$ during winter haze period around 2014 Chinese Spring Festival at Nanjing: Insights of source changes, air mass direction and firework particle injection, Sci. Total Environ., 520, 59-72, https://doi.org/10.1016/j.scitotenv.2015.03.001, 2015.

Lei, Y., Zhang, Q., He, K. B., and Streets, D. G.: Primary anthropogenic aerosol emission trends for China, 1990-2005, Atmos. Chem. Phys., 11, 931-954, https://doi.org/10.5194/acp-11-9312011, 2011.

Li, J., Du, H., Wang, Z., Sun, Y., Yang, W., Li, J., Tang, X., and Fu, P.: Rapid formation of a severe regional winter haze episode over a mega-city cluster on the North China Plain, Environ. Pollut., 223, 605-615, https://doi.org/10.1016/j.envpol.2017.01.063, 2017.

Li, J., Nagashima, T., Kong, L., Ge, B., Yamaji, K., Fu, J. S., Wang, X., Fan, Q., Itahashi, S., Lee, H.-J., Kim, C.-H., Lin, C.-Y., Zhang, M., Tao, Z., Kajino, M., Liao, H., Li, M., Woo, J.-H., Kurokawa, J.-I., Wu, Q., Akimoto, H., Carmichael, G. R., and 
Wang, Z.: Model evaluation and inter-comparison of surfacelevel ozone and relevant species in East Asia in the context of MICS-Asia phase III Part I: overview, Atmos. Chem. Phys. Discuss., https://doi.org/10.5194/acp-2018-1283, in review, 2019.

Li, K., Liao, H., Mao, Y., and Ridley, D. A.: Source sector and region contributions to concentration and direct radiative forcing of black carbon in China, Atmos. Environ., 124, 351-366, https://doi.org/10.1016/j.atmosenv.2015.06.014, 2016.

Li, K., Liao, H., Cai, W., and Yang, Y.: Attribution of Anthropogenic Influence on Atmospheric Patterns Conducive to Recent Most Severe Haze Over Eastern China, Geophys. Res. Lett., 45, 2072-2081, https://doi.org/10.1002/2017gl076570, 2018.

Li, K., Jacob, D. J., Liao, H., Shen, L., Zhang, Q., and Bates, K. H.: Anthropogenic drivers of 2013-2017 trends in summer surface ozone in China, P. Natl. Acad. Sci. USA, 116, 422-427, https://doi.org/10.1073/pnas.1812168116, 2019.

Li, M., Zhang, Q., Kurokawa, J.-I., Woo, J.-H., He, K., Lu, Z., Ohara, T., Song, Y., Streets, D. G., Carmichael, G. R., Cheng, Y., Hong, C., Huo, H., Jiang, X., Kang, S., Liu, F., Su, H., and Zheng, B.: MIX: a mosaic Asian anthropogenic emission inventory under the international collaboration framework of the MICS-Asia and HTAP, Atmos. Chem. Phys., 17, 935-963, https://doi.org/10.5194/acp-17-935-2017, 2017.

Li, N., Lu, Y., Liao, H., He, Q., Li, J., and Long, X.: WRF-Chem modeling of particulate matter in the Yangtze River Delta region: Source apportionment and its sensitivity to emission changes, PLoS ONE, 13, 0208944, https://doi.org/10.1371/journal.pone.0208944, 2018.

Li, Y., An, J., and Gultepe, I.: Effects of additional HONO sources on visibility over the North China Plain, Adv. Atmos. Sci., 31, 1221-1232, https://doi.org/10.1007/s00376-014-4019-1, 2014.

Li, Z., Li, C., Chen, H., Tsay, S. C., Holben, B., Huang, J., Li, B., Maring, H., Qian, Y., Shi, G., Xia, X., Yin, Y., Zheng, Y., and Zhuang, G.: East Asian Studies of Tropospheric Aerosols and their Impact on Regional Climate (EAST-AIRC): An overview, J. Geophys. Res., 116, D00K34, https://doi.org/10.1029/2010jd015257, 2011.

Li, Z., Rosenfeld, D., and Fan, J.: Aerosols and their impact on radiation, clouds, precipitation, and severe weather events, Oxford Research Encyclopedias, https://doi.org/10.1093/acrefore/9780199389414.013.126, $2017 \mathrm{a}$.

Li, Z., Guo, J., Ding, A., Liao, H., Liu, J., Sun, Y., Wang, T., Xue, H., Zhang, H., and Zhu, B.: Aerosol and boundary-layer interactions and impact on air quality, Nat. Sci. Rev., 4, 810-833, https://doi.org/10.1093/nsr/nwx117, 2017b.

Liu, Q., Jia, X., Quan, J., Li, J., Li, X., Wu, Y., Chen, D., Wang, Z., and Liu, Y.: New positive feedback mechanism between boundary layer meteorology and secondary aerosol formation during severe haze events, Sci. Rep., 8, 6095, https://doi.org/10.1038/s41598-018-24366-3, 2018.

Liu, Z., Gao, W., Yu, Y., Hu, B., Xin, J., Sun, Y., Wang, L., Wang, G., Bi, X., Zhang, G., Xu, H., Cong, Z., He, J., Xu, J., and Wang, Y.: Characteristics of $\mathrm{PM}_{2.5}$ mass concentrations and chemical species in urban and background areas of China: emerging results from the CARE-China network, Atmos. Chem. Phys., 18, 88498871, https://doi.org/10.5194/acp-18-8849-2018, 2018.

Lo, J. C.-F., Yang, Z.-L., and Pielke, R. A.: Assessment of three dynamical climate downscaling methods using the Weather Re- search and Forecasting (WRF) model, J. Geophys. Res., 113, D09112, https://doi.org/10.1029/2007jd009216, 2008.

Lou, S., Yang, Y., Wang, H., Smith, S. J., Qian, Y., and Rasch, P. J.: Black carbon amplifies haze over the North China Plain by weakening the East Asian winter monsoon, Geophys. Res. Lett., 46, 452-460, https://doi.org/10.1029/2018GL080941, 2019.

Otte, T. L.: The Impact of Nudging in the Meteorological Model for Retrospective Air Quality Simulations. Part I: Evaluation against National Observation Networks, J. Appl. Meteorol. Clim., 47, 1853-1867, https://doi.org/10.1175/2007jamc1790.1, 2008.

Petaja, T., Jarvi, L., Kerminen, V. M., Ding, A. J., Sun, J. N., Nie, W., Kujansuu, J., Virkkula, A., Yang, X. Q., Fu, C. B., Zilitinkevich, S., and Kulmala, M.: Enhanced air pollution via aerosol-boundary layer feedback in China, Sci. Rep., 6, 18998, https://doi.org/10.1038/srep18998, 2016.

Qian, Y., Yan, H., Berg, L. K., Hagos, S., Feng, Z., Yang, B., and Huang, M.: Assessing Impacts of PBL and Surface Layer Schemes in Simulating the Surface-Atmosphere Interactions and Precipitation over the Tropical Ocean Using Observations from AMIE/DYNAMO, J. Climate, 29, 8191-8210, https://doi.org/10.1175/jcli-d-16-0040.1, 2016.

Qiu, Y., Liao, H., Zhang, R., and Hu, J.: Simulated impacts of direct radiative effects of scattering and absorbing aerosols on surface layer aerosol concentrations in China during a heavily polluted event in February 2014, J. Geophys. Res.-Atmos., 122, 59555975, https://doi.org/10.1002/2016jd026309, 2017.

Ramanathan, V., Crutzen, P. J., Kiehl, J. T., and Rosenfeld, D.: Aerosols, climate, and the hydrological cycle, Science, 294, 2119-2124, https://doi.org/10.1126/science.1064034, 2001.

Randerson, J. T., Van der Werf, G. R., Giglio, L., Collatz, G. J., and Kasibhatla, P. S.: Global Fire Emissions Database, Version 2 (GFEDv2.1), available at: http://daac.ornl.gov/ (last access: 11 November 2013), from Oak Ridge National Laboratory Distributed Active Archive Center, Oak Ridge, TN, https://doi.org/10.3334/ORNLDAAC/849, 2005.

Rolph, G. D.: Real-time Environmental Applications and Display System (READY), NOAA Air Resources Laboratory, Silver Spring, MD, available at: http://ready.arl.noaa.gov, 2013.

Shao, Y.: Simplification of a dust emission scheme and comparison with data, J. Geophys. Res., 109, D10202, https://doi.org/10.1029/2003jd004372, 2004.

Shu, L., Xie, M., Gao, D., Wang, T., Fang, D., Liu, Q., Huang, A., and Peng, L.: Regional severe particle pollution and its association with synoptic weather patterns in the Yangtze River Delta region, China, Atmos. Chem. Phys., 17, 12871-12891, https://doi.org/10.5194/acp-17-12871-2017, 2017.

Skamarock, W. C., Klemp, J. B., Dudhia, J., Gill, D. O., Barker, D. M., Wang, W., and Powers, J. G.: A description of the advanced research WRF version 2, NCAR Tech. Note, NCAR/TN468+STR, Natl. Cent. Atmos. Res., Boulder, Colo, available at: http://wrf-model.org/wrfadmin/publications.php (last access: 12 August 2019), 2008.

Steiner, A. L., Mermelstein, D., Cheng, S. J., Twine, T. E., and Oliphant, A.: Observed Impact of Atmospheric Aerosols on the Surface Energy Budget, Earth Interact., 17, 1-22, https://doi.org/10.1175/2013ei000523.1, 2013.

Su, T., Li, Z., and Kahn, R.: Relationships between the planetary boundary layer height and surface pollutants derived from lidar observations over China: regional pattern and in- 
fluencing factors, Atmos. Chem. Phys., 18, 15921-15935, https://doi.org/10.5194/acp-18-15921-2018, 2018.

Sun, J., Huang, L., Liao, H., Li, J., and Hu, J.: Impacts of Regional Transport on Particulate Matter Pollution in China: a Review of Methods and Results, Current Pollution Reports, 3, 182-191, https://doi.org/10.1007/s40726-017-0065-5, 2017.

Sun, Y., Jiang, Q., Wang, Z., Fu, P., Li, J., Yang, T., and Yin, Y.: Investigation of the Sources and Evolution Processes of Severe Haze Pollution in Beijing in January 2013, J. Geophys. Res., 119, 4380-4398, 2014.

Sun, Y., Chen, C., Zhang, Y., Xu, W., Zhou, L., Cheng, X., Zheng, H., Ji, D., Li, J., Tang, X., Fu, P., and Wang, Z.: Rapid formation and evolution of an extreme haze episode in Northern China during winter 2015, Sci. Rep., 6, 27151, https://doi.org/10.1038/srep27151, 2016.

Tang, G., Zhu, X., Xin, J., Hu, B., Song, T., Sun, Y., Zhang, J., Wang, L., Cheng, M., Chao, N., Kong, L., Li, X., and Wang, Y.: Modelling study of boundary-layer ozone over northern China - Part I: Ozone budget in summer, Atmos. Res., 187, 128-137, https://doi.org/10.1016/j.atmosres.2016.10.017, 2017.

Tao, W., Liu, J., Ban-Weiss, G. A., Hauglustaine, D. A., Zhang, L., Zhang, Q., Cheng, Y., Yu, Y., and Tao, S.: Effects of urban land expansion on the regional meteorology and air quality of eastern China, Atmos. Chem. Phys., 15, 8597-8614, https://doi.org/10.5194/acp-15-8597-2015, 2015.

Twomey, S.: Pollution and the planetary albedo, Atmos. Environ., 8, 1251-1256, https://doi.org/10.1016/0004-6981(74)90004-3, 1974.

Unger, N., Menon, S., Koch, D. M., and Shindell, D. T.: Impacts of aerosol-cloud interactions on past and future changes in tropospheric composition, Atmos. Chem. Phys., 9, 4115-4129, https://doi.org/10.5194/acp-9-4115-2009, 2009.

Wang, H., Zhu, B., Shen, L., Xu, H., An, J., Pan, C., Li, Y. E., and Liu, D.: Regional Characteristics of Air Pollutants during Heavy Haze Events in the Yangtze River Delta, China, Aerosol Air Qual. Res., 16, 2159-2171, https://doi.org/10.4209/aaqr.2015.09.0551, 2016.

Wang, L., Zhang, Y., Wang, K., Zheng, B., Zhang, Q., and Wei, W.: Application of Weather Research and Forecasting Model with Chemistry (WRF/Chem) over northern China: Sensitivity study, comparative evaluation, and policy implications, Atmos. Environ., 124, 337-350, https://doi.org/10.1016/j.atmosenv.2014.12.052, 2016.

Wang, Y., Yao, L., Wang, L., Liu, Z., Ji, D., Tang, G., Zhang, J., Sun, Y., Hu, B., and Xin, J.: Mechanism for the formation of the January 2013 heavy haze pollution episode over central and eastern China, Science China Earth Sciences, 57, 14-25, https://doi.org/10.1007/s11430-013-4773-4, 2013.

Wang, Y., Zhang, Q., Jiang, J., Zhou, W., Wang, B., He, K., Duan, F., Zhang, Q., Philip, S., and Xie, Y.: Enhanced sulfate formation during China's severe winter haze episode in January 2013 missing from current models, J. Geophys. Res.-Atmos., 119, 10425410440, https://doi.org/10.1002/2013jd021426, 2014.

Wang, Y., Bao, S., Wang, S., Hu, Y., Shi, X., Wang, J., Zhao, B., Jiang, J., Zheng, M., Wu, M., Russell, A. G., Wang, Y., and Hao, J.: Local and regional contributions to fine particulate matter in Beijing during heavy haze episodes, Sci. Total Environ., 580, 283-296, https://doi.org/10.1016/j.scitotenv.2016.12.127, 2017.
Wang, Z., Li, J., Wang, Z., Yang, W., Tang, X., Ge, B., Yan, P., Zhu, L., Chen, X., Chen, H., Wand, W., Li, J., Liu, B., Wang, X., Wand, W., Zhao, Y., Lu, N., and Su, D.: Modeling study of regional severe hazes over mid-eastern China in January 2013 and its implications on pollution prevention and control, Science China Earth Sciences, 57, 3-13, https://doi.org/10.1007/s11430013-4793-0, 2013.

Werner, M., Kryza, M., Skjøth, C. A., Kinga, W., Anthony, J. D., Hanna, O., and Jan, K.: Aerosol-radiation feedback and PM $_{10}$ air concentrations over Poland, Pure Appl. Geophys., 174, 99-110, https://doi.org/10.1007/s00024-016-1267-2, 2016.

Wesely, M. L.: Parameterization of surface resistances to gaseous dry deposition in regional-scale numerical models, Atmos. Environ., 23, 1293-1304, https://doi.org/10.1016/00046981(89)90153-4, 1989.

Wild, O., Zhu, X., and Prather, M. J.: Fast-J: Accurate Simulation of In and Below-Cloud Photolysis in Tropospheric Chemical Models, J. Atmos. Chem., 37, 245-282, https://doi.org/10.1023/A:1006415919030, 2000.

Wu, L., Su, H., Jiang, J. H., and Read, W. G.: Hydration or dehydration: competing effects of upper tropospheric cloud radiation on the TTL water vapor, Atmos. Chem. Phys., 12, 7727-7735, https://doi.org/10.5194/acp-12-7727-2012, 2012.

Xing, J., Wang, J., Mathur, R., Wang, S., Sarwar, G., Pleim, J., Hogrefe, C., Zhang, Y., Jiang, J., Wong, D. C., and Hao, J.: Impacts of aerosol direct effects on tropospheric ozone through changes in atmospheric dynamics and photolysis rates, Atmos. Chem. Phys., 17, 9869-9883, https://doi.org/10.5194/acp-179869-2017, 2017.

Yahya, K., Wang, K., Gudoshava, M., Glotfelty, T., and Zhang, Y.: Application of WRF/Chem over North America under the AQMEII Phase 2: Part I. Comprehensive evaluation of 2006 simulation, Atmos. Environ., 115, 733-755, https://doi.org/10.1016/j.atmosenv.2014.08.063, 2015.

Yang, J., Duan, K., Kang, S., Shi, P., and Ji, Z.: Potential feedback between aerosols and meteorological conditions in a heavy pollution event over the Tibetan Plateau and Indo-Gangetic Plain, Clim. Dynam., 48, 2901-2917, https://doi.org/10.1007/s00382016-3240-2, 2016.

Yang, Y., Liao, H., and Lou, S.: Increase in winter haze over eastern China in recent decades: Roles of variations in meteorological parameters and anthropogenic emissions, J. Geophys. Res.-Atmos., 121, 13050-13065, https://doi.org/10.1002/2016jd025136, 2016.

Yang, Y., Russell, L. M., Lou, S., Liao, H., Guo, J., Liu, Y., Singh, B., and Ghan, S. J.: Dust-wind interactions can intensify aerosol pollution over eastern China, Nat. Commun., 8, 15333, https://doi.org/10.1038/ncomms15333, 2017.

Zaveri, R. A. and Peters, L. K.: A new lumped structure photochemical mechanism for large-scale applications, J. Geophys. Res.-Atmos., 104, 30387-30415, https://doi.org/10.1029/1999jd900876, 1999.

Zaveri, R. A., Easter, R. C., Fast, J. D., and Peters, L. K.: Model for Simulating Aerosol Interactions and Chemistry (MOSAIC), J. Geophys. Res., 113, D13204, https://doi.org/10.1029/2007jd008782, 2008.

Zhang, B., Wang, Y., and Hao, J.: Simulating aerosol-radiationcloud feedbacks on meteorology and air quality over eastern China under severe haze conditionsin winter, Atmos. 
Chem. Phys., 15, 2387-2404, https://doi.org/10.5194/acp-152387-2015, 2015.

Zhang, L., Guo, X., Zhao, T., Gong, S., Xu, X., Li, Y., Luo, L., Gui, K., Wang, H., Zheng, Y., and Yin, X.: A modelling study of the terrain effects on haze pollution in the Sichuan Basin, Atmos. Environ., 196, 77-85, https://doi.org/10.1016/j.atmosenv.2018.10.007, 2019.

Zhang, R., Sun, X., Shi, A., Huang, Y., Yan, J., Nie, T., Yan, X., and $\mathrm{Li}, \mathrm{X}$.: Secondary inorganic aerosols formation during haze episodes at an urban site in Beijing, China, Atmos. Environ., 177, 275-282, https://doi.org/10.1016/j.atmosenv.2017.12.031, 2018.

Zhang, Y., Dubey, M. K., Olsen, S. C., Zheng, J., and Zhang, R.: Comparisons of WRF/Chem simulations in Mexico City with ground-based RAMA measurements during the 2006-MILAGRO, Atmos. Chem. Phys., 9, 3777-3798, https://doi.org/10.5194/acp-9-3777-2009, 2009.

Zhang, Y., Chen, Y., Sarwar, G., and Schere, K.: Impact of gasphase mechanisms on Weather Research Forecasting Model with Chemistry (WRF/Chem) predictions: Mechanism implementation and comparative evaluation, J. Geophys. Res.-Atmos., 117, D01301, https://doi.org/10.1029/2011jd015775, 2012.

Zhang, Z., Xu, X., Qiao, L., Gong, D., Kim, S. J., Wang, Y., and Mao, R.: Numerical simulations of the effects of regional topography on haze pollution in Beijing, Sci. Rep., 8, 5504, https://doi.org/10.1038/s41598-018-23880-8, 2018.

Zhao, C., Liu, X., Leung, L. R., Johnson, B., McFarlane, S. A., Gustafson Jr., W. I., Fast, J. D., and Easter, R.: The spatial distribution of mineral dust and its shortwave radiative forcing over North Africa: modeling sensitivities to dust emissions and aerosol size treatments, Atmos. Chem. Phys., 10, 8821-8838, https://doi.org/10.5194/acp-10-8821-2010, 2010.

Zhao, C., Liu, X., Ruby Leung, L., and Hagos, S.: Radiative impact of mineral dust on monsoon precipitation variability over West Africa, Atmos. Chem. Phys., 11, 1879-1893, https://doi.org/10.5194/acp-11-1879-2011, 2011.

Zhao, C., Ruby Leung, L., Easter, R., Hand, J., and Avise, J.: Characterization of speciated aerosol direct radiative forcing over California, J. Geophys. Res.-Atmos., 118, 2372-2388, https://doi.org/10.1029/2012jd018364, 2013.
Zhao, B., Liou, K. N., Gu, Y., Li, Q., Jiang, J. H., Su, H., He, C., Tseng, H. R., Wang, S., Liu, R., Qi, L., Lee, W. L., and Hao, J.: Enhanced $\mathrm{PM}_{2.5}$ pollution in China due to aerosol-cloud interactions, Sci. Rep., 7, 4453, https://doi.org/10.1038/s41598-01704096-8, 2017.

Zhao, S., Yu, Y., Yin, D., Qin, D., He, J., and Dong, L.: Spatial patterns and temporal variations of six criteria air pollutants during 2015 to 2017 in the city clusters of Sichuan Basin, China, Sci. Total Environ., 624, 540-557, https://doi.org/10.1016/j.scitotenv.2017.12.172, 2018.

Zheng, B., Tong, D., Li, M., Liu, F., Hong, C., Geng, G., Li, H., Li, X., Peng, L., Qi, J., Yan, L., Zhang, Y., Zhao, H., Zheng, Y., He, K., and Zhang, Q.: Trends in China's anthropogenic emissions since 2010 as the consequence of clean air actions, Atmos. Chem. Phys., 18, 14095-14111, https://doi.org/10.5194/acp-18-140952018, 2018.

Zheng, G. J., Duan, F. K., Su, H., Ma, Y. L., Cheng, Y., Zheng, B., Zhang, Q., Huang, T., Kimoto, T., Chang, D., Pöschl, U., Cheng, Y. F., and He, K. B.: Exploring the severe winter haze in Beijing: the impact of synoptic weather, regional transport and heterogeneous reactions, Atmos. Chem. Phys., 15, 2969-2983, https://doi.org/10.5194/acp-15-2969-2015, 2015.

Zhou, M., Zhang, L., Chen, D., Gu, Y., Fu, T.-M., Gao, M., Zhao, Y., Lu, X., and Zhao, B.: The impact of aerosol-radiation interactions on the effectiveness of emission control measures, Environ. Res. Lett., 14, 024002, https://doi.org/10.1088/17489326/aaf27d, 2018.

Zhu, B., Kang, H. Q., Zhu, T., Su, J. F., Hou, X. W., and Gao, J. H.: Impact of Shanghai urban land surface forcing on downstream city ozone chemistry, J. Geophys. Res.-Atmos., 120, 4340-4351, https://doi.org/10.1002/2014JD022859, 2015.

Zhu, J., Chen, L., Liao, H., and Dang, R.: Correlations between $\mathrm{PM}_{2.5}$ and Ozone over China and Associated Underlying Reasons, Atmosphere, 352, 1-15, https://doi.org/10.3390/atmos10070352, 2019. 